\title{
Light Truck Forecasts
}

\author{
G. E. Liepins
}

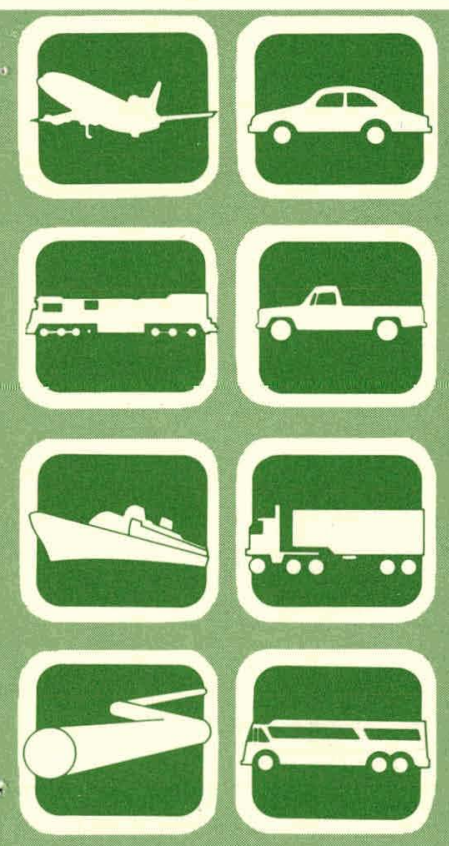




\section{DISCLAIMER}

This report was prepared as an account of work sponsored by an agency of the United States Government. Neither the United States Government nor any agency Thereof, nor any of their employees, makes any warranty, express or implied, or assumes any legal liability or responsibility for the accuracy, completeness, or usefulness of any information, apparatus, product, or process disclosed, or represents that its use would not infringe privately owned rights. Reference herein to any specific commercial product, process, or service by trade name, trademark, manufacturer, or otherwise does not necessarily constitute or imply its endorsement, recommendation, or favoring by the United States Government or any agency thereof. The views and opinions of authors expressed herein do not necessarily state or reflect those of the United States Government or any agency thereof. 


\section{DISCLAIMER}

Portions of this document may be illegible in electronic image products. Images are produced from the best available original document. 


\section{Printed in the United States of America. Available from} National Technical Information Service

U.S. Department of Commerce 5285 Port Royal Road, Springfield, Virginia 22161

Price: Printed Copy $\$ 5.25$; Microfiche $\$ 3.00$

This report was prepared as an account of work sponsored by an agency of the United States Government. Neither the United States Government nor any agency thereof, nor any of their employees, contractors, subcontractors, or their employees, makes any warranty, express or implied, nor assumes any legal liability or responsibility for any third party's use or the results of such use of any information, apparatus, product or process disclosed in this report, nor represents that its use by such third party would not-infringe privately owned rights. 
Contract No. W-7405-eng-26

\title{
LIGHT TRUCK FORECASTS
}

G. E. Liepins

\section{Regional and Urban Studies Section Energy Division}

\author{
Prepared for \\ Data Analysis Branch \\ Nonhighway Transport Systems and Special Projects \\ Transportation Programs \\ Office of Conservation and Solar Applications \\ Department of Energy
}

Date Published - September 1979

OAK RIDGE NATIONAL LABORATORY

Oak Ridge, Tennessee 37830

Operated by

UNION CARBIDE CORPORATION

for the

DEPARTMENT OF ENERGY

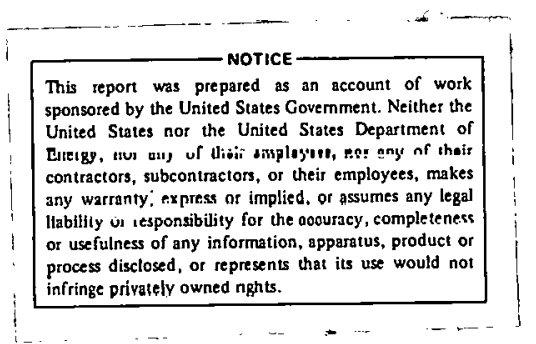


THIS PAGE

WAS INTENTIONALLY

LEFT BLANK 


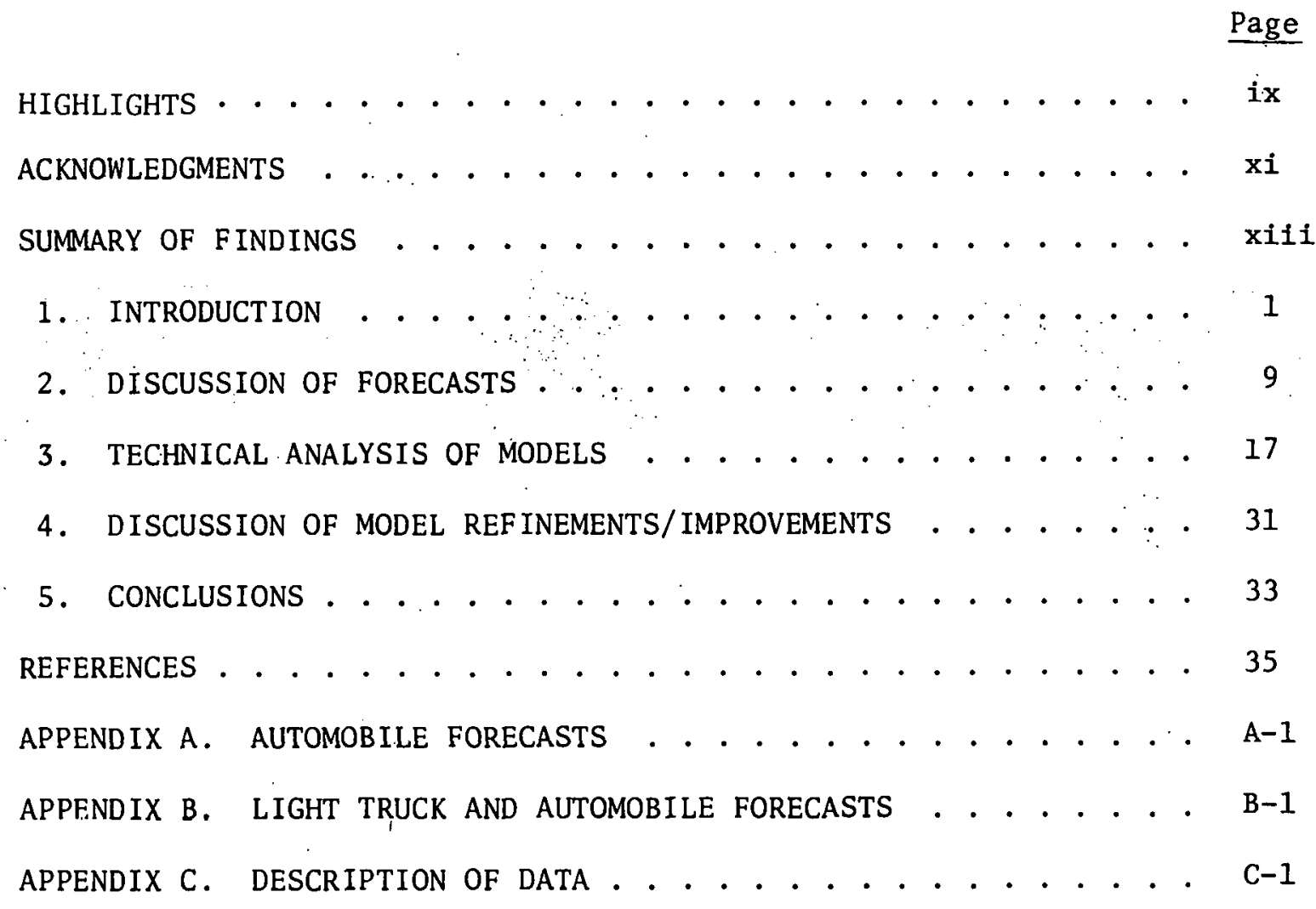


THIS PAGE

WAS INTENTIONALLY

LEFT BLANK 


\section{LIST OF TABLES}

Table

1.1 Total Count of Light. Trucks $\times 10^{3}$. . . . . . . . . . 5

1.2 Percent Distribution of Light Trucks by Major Use . . . . . 6

1.3 Parameter Values for Scenarios Applied to ORNL Models . . . 7

2.1 Growth Rates of GNP and Sector Outputs Used in the Trucking Projections .................. . 16

B.1 Projections of Light. Trucks and Cars for Cases I and IIA, Models A and B, 1975-2000 . . . . . . . . . B-3

C.1 Description of Data . . . . . . . . . . . . . ${ }^{\mathrm{C}-3}$ 


\section{THIS PAGE}

\section{WAS INTENTIONALLY LEFT BLANK}




\section{LIST OF FIGURES}

$\underline{\text { Figure }}$

1.1 Light Truck Forecast, Case I . . . . . . . . . . . 2

1.2 Light Truck Forecast, Case II . . . . . . . . . . 3

1.3 Light Truck Forecast, Case IIA . . . . . . . . . . . . 3

1.4 Light Truck Forecast, Case III . . . . . . . . . . . 4

1.5 Light Truck Forecast, Case IV . . . . . . . . . . . . 4

1.6 Light Truck Forecast, Hirst Data . . . . . . . . . . 5

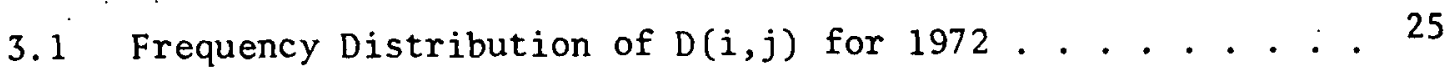

3.2 Frequency Distribution of $\mathrm{nLr}$ for 1972 . . . . . . . . 25

A.1 Automobile Forecast, Case I . . . . . . . . . . . A-3

A.2 Automobile Forecast, Case II . . . . . . . . . . . A-3

A.3 Automobile Forecast, Case IIA . . . . . . . . . . . A-4

A.4 Automobile Forecast, Case III . . . . . . . . . . . A-4

A.5 Automobile Forecast, Case IV . . . . . . . . . . A-5

A.6 Automobile Forecast, Hirst Data . . . . . . . . . . A-5 
THIS PAGE

WAS INTENTIONALLY

LEFT BLANK 


\section{HIGHLIGHTS}

The recent dramatic increase in the number of light trucks ( $109 \%$. between 1963 and 1974) has prompted concern about the energy consequences of the growing popularity of the light truck. An estimate of the future number of light trucks is considered to be a reasonable first step in assessing the energy impact of these vehicles. This monograph contains forecasts based on two models and six scenarios. The coefficients for the models have been derived by ordinary least squares regression of national level time series data. The first model is a two stage mode1: The first stage estimates the number of light trucks and cars (together), and the second stage applies a share's submodel to determine the number of light trucks. The second model is a simultaneous equation model. The two models track one another remarkably well, within about $2 \%$. The scenarios were chosen to be consistent with those used in the LindseyKaufman study Projection of Light Truck Population to Year 2025. Except in the case of the most dismal economic scenario, the number of light trucks is expected to increase from the 1974 level of 0.09 1ight truck per person to about 0.12 light truck per person in 1995. 


\section{THIS PAGE \\ WAS INTENTIONALLY \\ LEFT BLANK}




\section{ACKNOWLEDGMENTS}

I wish to express my appreciation of the people who contributed to this work: Phil Patterson for requesting the study, Steve Corey who assisted in the programming, Steve Cohn for lively discussions of appropriate models, and David Greene and John Trimble for their valuable comments. 
THIS PAGE

WAS INTENTIONALLY

LEFT BLANK 
According to the Truck Inventory and Use Survey, in 1972, $14.598 \times 10^{6}$ light trucks were registered in the United States. By 1995, that number is expected to increase to about $30 \times 10^{6}$ for the scenario considered most 1 ikely by Lindsey-Kaufman, ${ }^{1}$ Case IIA. Except in the case of the most dismal economic scenario, the number of light trucks is expected to increase not only in numerical count, but also in terms of light truck per person ratios as well as light truck per car ratios. The 1972 light truck per person ratio was 0.075 , and is predicted to be $0.12-0.13$ by 1.995 (Case IIA). The light truck per car ratio, which was 0.16 in 1972 , is forecast to be 0.20 in 1995. Under future economic and technological conditions not drastically different from the present, the general agreement is that the number of light trucks will increase. It is also a matter of general concensus that the rate of growth in the light truck per person ratio will ultimately slow; only the timing and the magnitude of the slowing is in debate.

Theoretically, inventories of light trucks depend on at least two types of factors: First, economic and population factors, and second, consumer tastes (because, to a degree, light trucks are substitutes for cars). Because of the inavailabity of appropriate data, the latter factor (consumer tastes) has not been explicitly captured in the formulation of these models. The models are driven primarily by personal disposable income and population; each has a significant positive influence on the number of vehicles, cars, and light trucks. Household size appears with a negative coefficient as an explanatory variable for the number of vehicles - a reasonable finding in that members of the same household are probably more likely to share the use of a vehicle than persons from different households. Unemployment also enters the vehicle equation with a negative coefficient. The remaining explanatory variable, age distribution between 15 and 45 , expressed as a percentage, enters significantly with a positive coefficient in each of the regression equations. Age distribution is discussed in greater detail in the section of this monograph devoted to technical analysis. 


\section{INTRODUCTION}

The purpose of this monograph is to provide forecasts under various economic conditions from 1975 through 2000 of the number of light trucks (i.e., trucks weighing less than or equal to $10,000 \mathrm{lb}$ ) registered in the continental United States. Light trucks have become a concern of the Transportation Programs Division of the Office of Conservation and Solar Applications, Department of Energy, because of the rapid increase in their numbers: the inventory of light trucks increased 109\% from 1963 through $1974,2-5$ while that of cars increased only $52 \%$ for the same period.

Sales statistics demonstrate this explosive growth more clearly. Sales of light trucks increased from $0.934 \times 10^{6}$ in 1963 to $2.256 \times 10^{6}$ in 1974, with a high of $2.556 \times 10^{6}$. in 1973. For the same years, car sales were $7.941 \times 10^{6}, 8.852 \times 10^{6}$, and $11.430 \times 10^{6}$ respectively. ${ }^{6}$ Data indicate that in 1963, the ratio of light trucks to cars sold was approximately 1:8.5, whereas in 1974 the ratio was $1: 4$. Even more dramatic is the fact that the Chevrolet Division of General Motors now sells one light truck for every 1.8 cars. The ratio in 1960 was one truck for every 6.3 cars. ${ }^{7}$ To be sure, the numerical increase in the number of trucks $\left(9.7 \times 10^{6}\right)$ is small in comparison to that of cars $\left(36.2 \times 10^{6}\right)$, yet if the growth of the number of light trucks continues at the present rate, light trucks could become a major factor in petroleum product consumption. This trend is further aggravated by the fact that light trucks historically have had poorer fuel economy than automobiles. (Estimates of intercity fuel economy for automobiles were $13.0 \mathrm{mpg}$ in 1972 for luxury automobiles; $18.0 \mathrm{mpg}$ for standard, $22.5 \mathrm{mpg}$ for compact, and $30.0 \mathrm{mpg}$ for subcompact, ${ }^{8}$ as opposed to $10.8-12.4 \mathrm{mpg}$ for light trucks. 9

This monograph provides forecasts for the number of light trucks under various economic conditions in the years 1975 through 2000.10 The projections are based on six scenarios: Cases I, II, IIA, III, and IV are those assumed by the Lindsey-Kaufman study. ' Case "Hirst Data" is based on projections by E. Hirst of Oak Ridge National Laboratory. 10 
The estimates in this study are the expected values generated for each scenario and, at best, are presumed to have validity only under socioeconomic-technological conditions not drastically different from the present.

This monograph presents data generated. by the two models, a discussion of the technical details of the models, and finally, conclusions.

Below are the projections derived from use of the models in conjunction with the scenarios considered. Figures 1.1 to 1.6 present the projections graphically, Tables 1.1 and 1.2 list the projerted numbers of light trucks for selected years, and Tahle 1.3 lists the paramotor. values for each scenario.

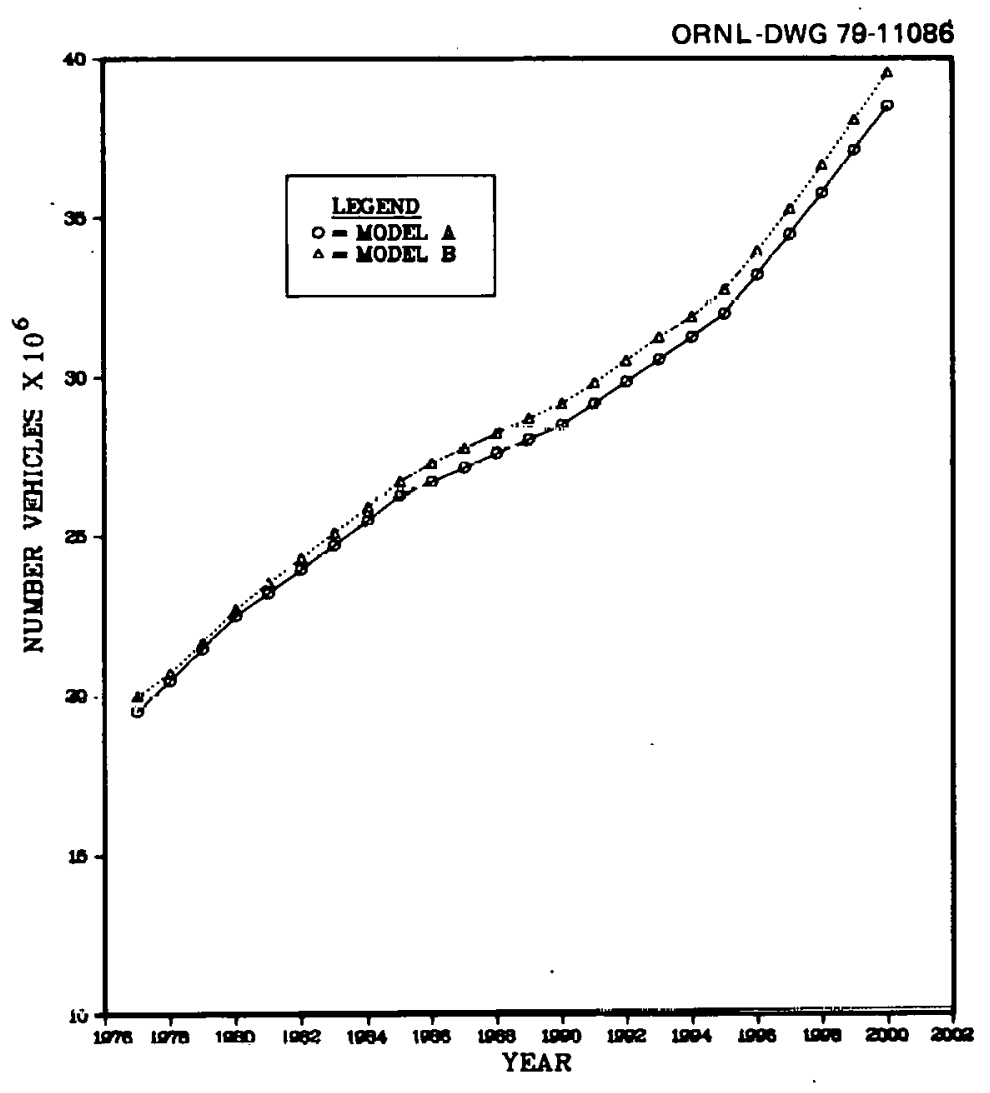

Fig. 1.1. Light Truck Forecast - Case I. 


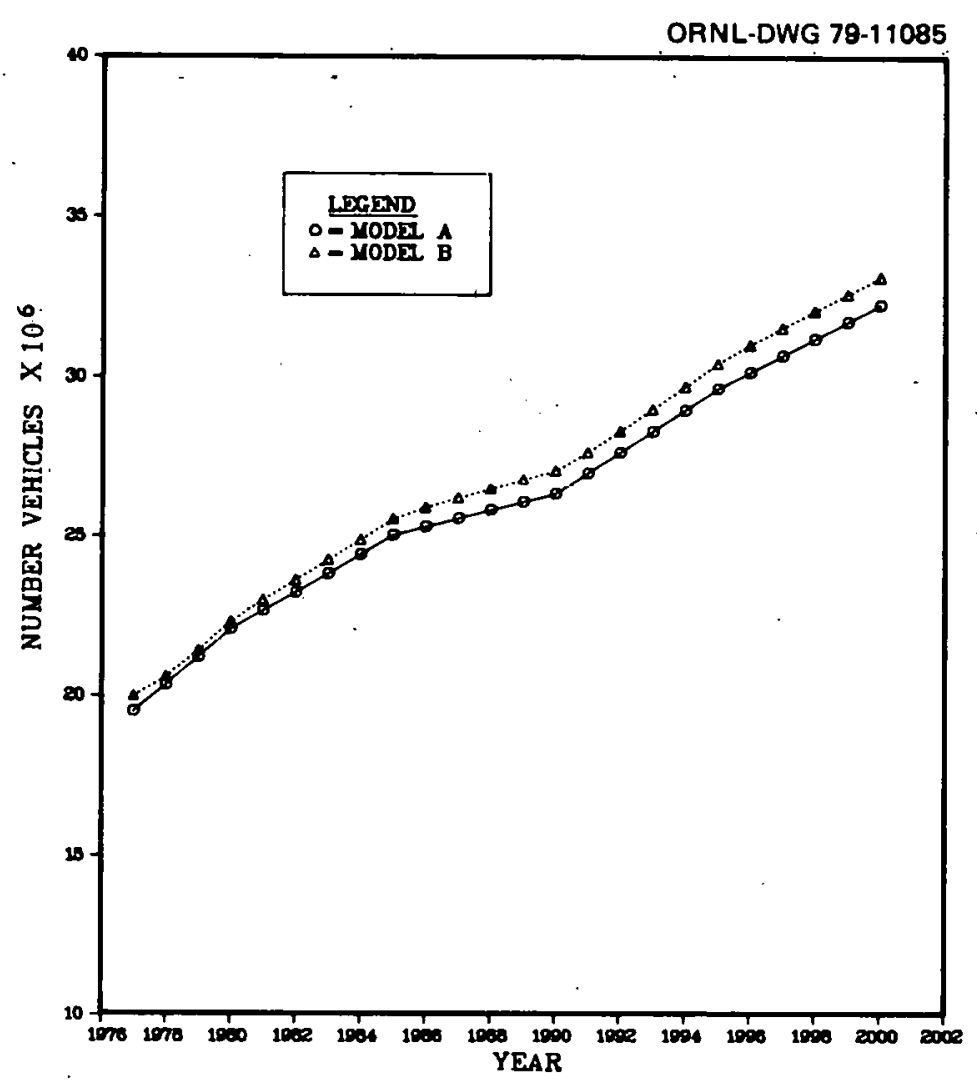

Fig. 1.2. Light Truck Forecast - Case II.

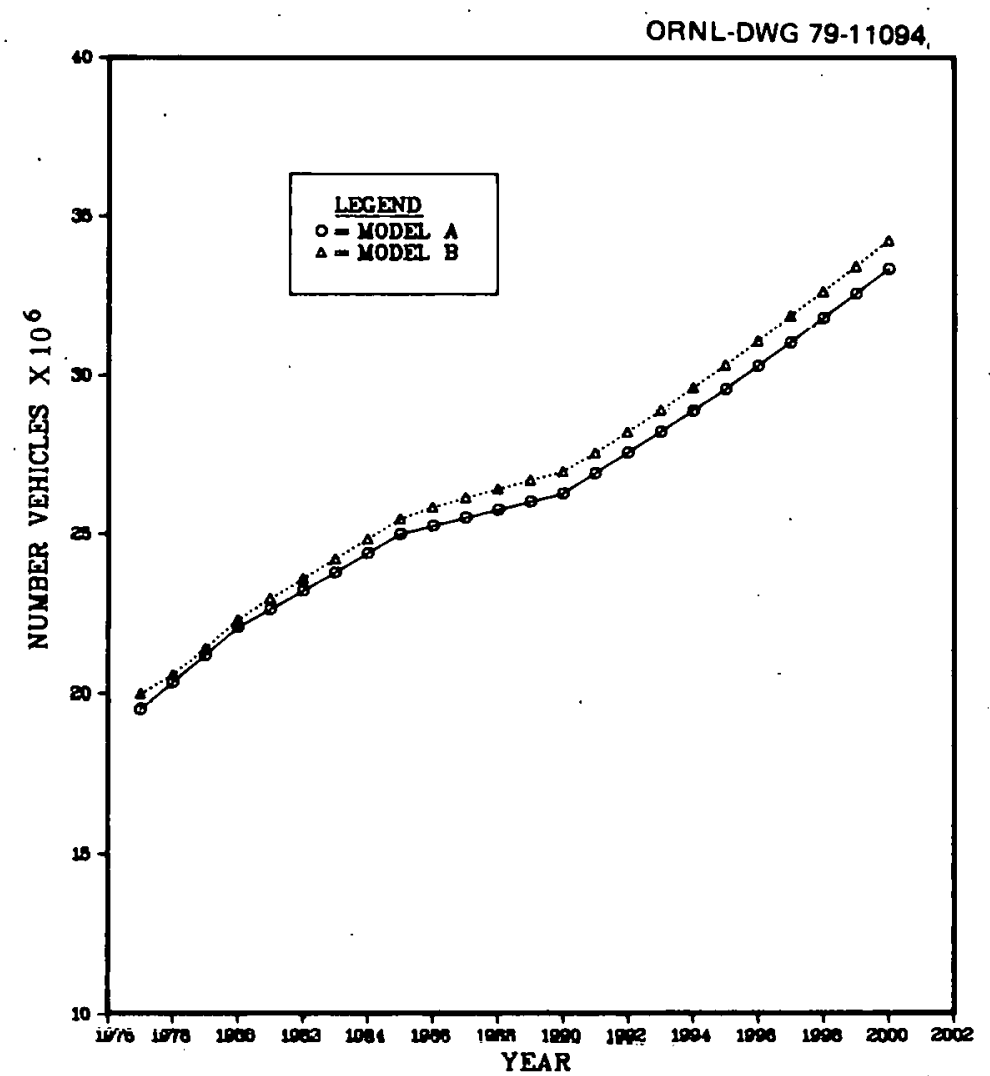

Fig. 1.3. Light Truck Forecast - Case IIA. 


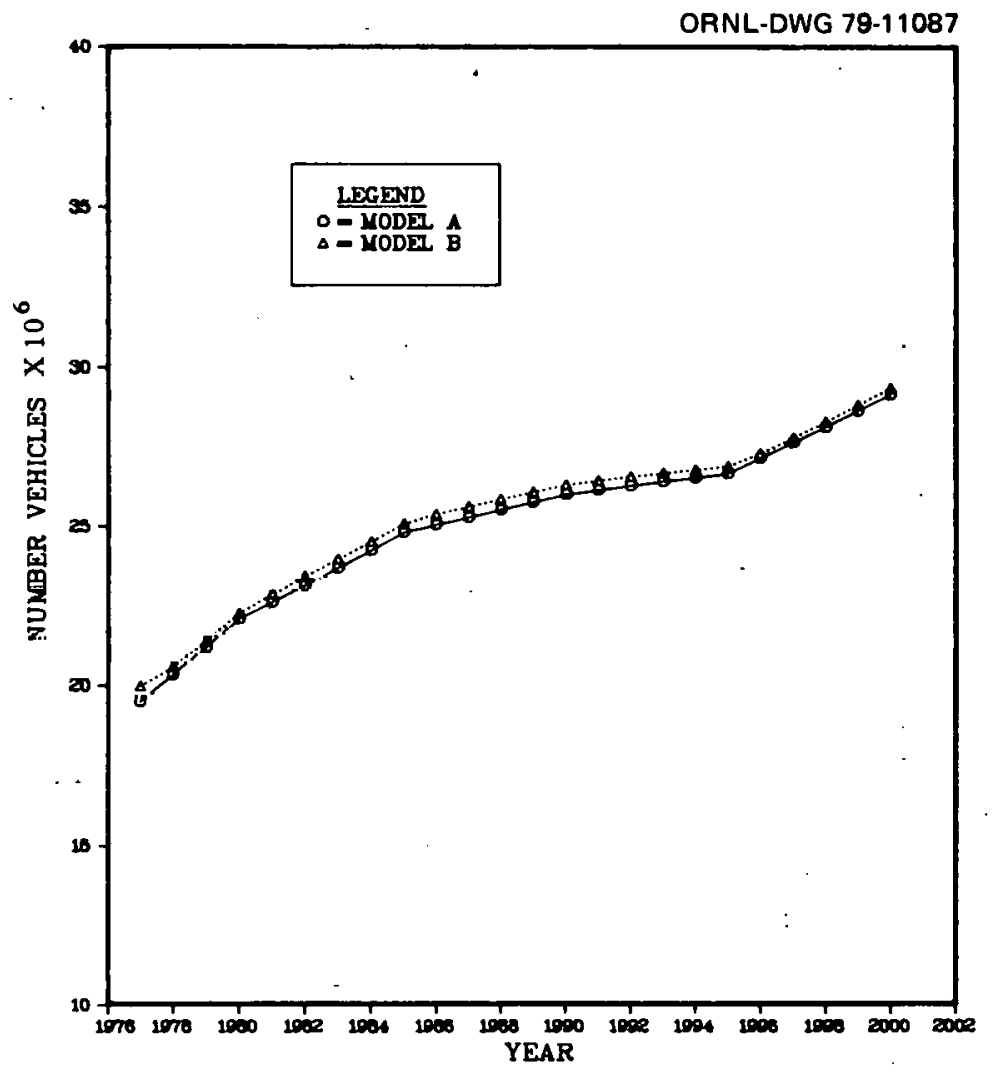

Fig. 1.4. Light Truck Forecast-Case III.

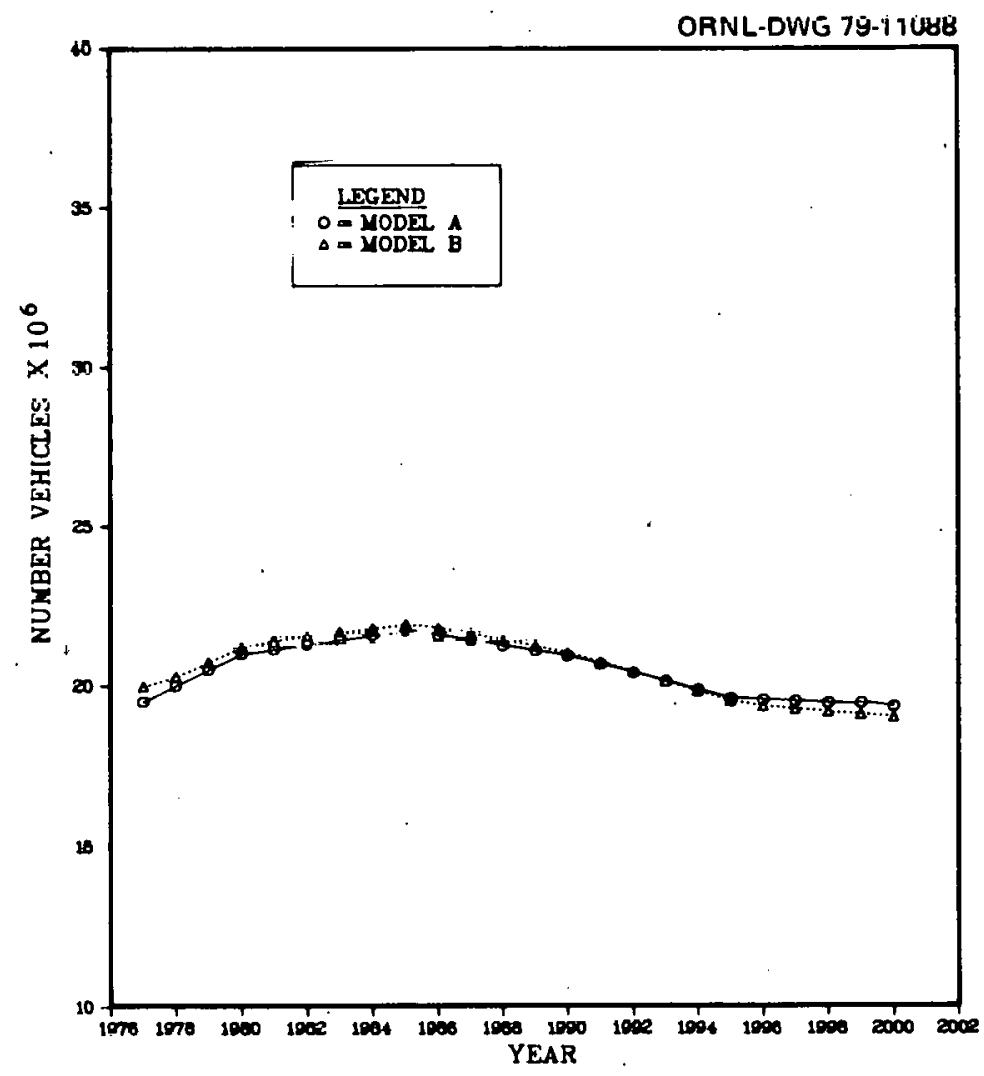

Fig. 1.5. Light Truck Forecast - Case IV. 


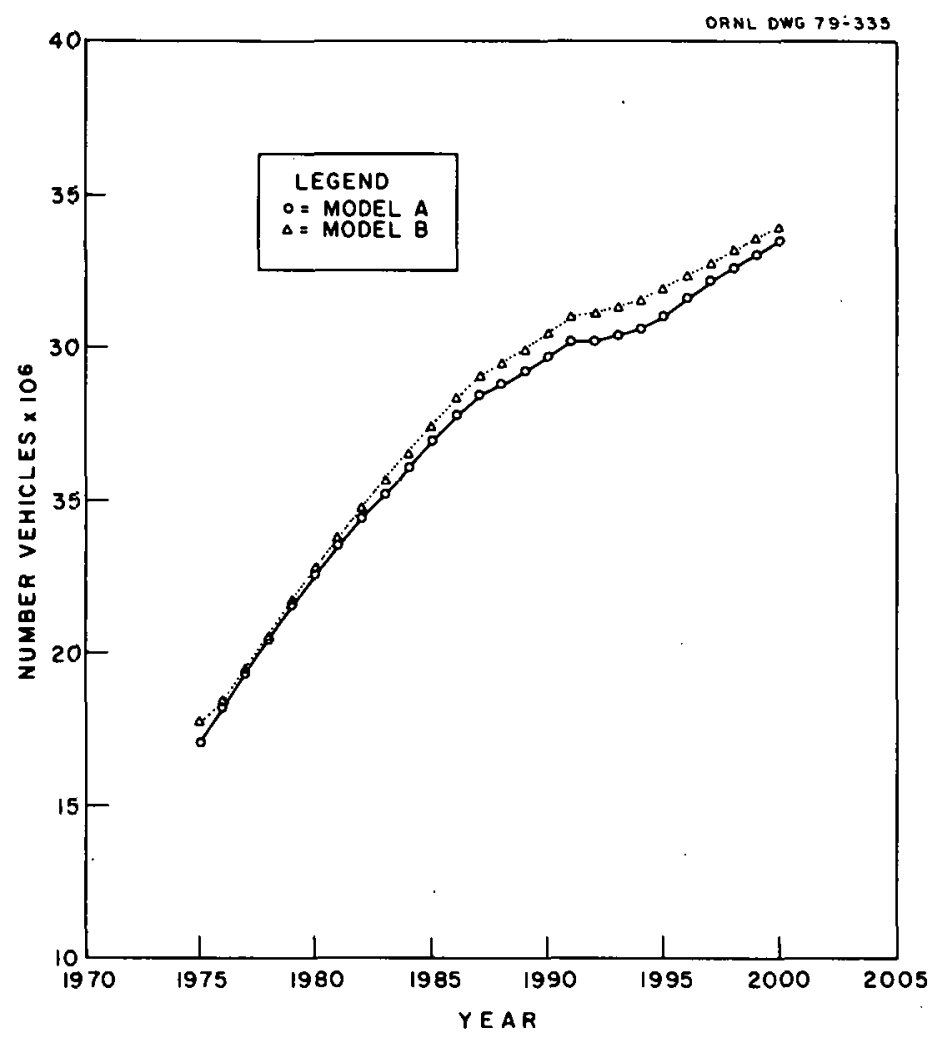

Fig. 1.6. Light Truck Forecast - Hirst Data.

Table 1.1. Total Count of Light Trucks $\times 10^{3}$

\begin{tabular}{|c|c|c|c|c|c|c|c|}
\hline \multirow[b]{2}{*}{ Case } & \multicolumn{3}{|c|}{$\begin{array}{c}\text { Truck Inventory and } \\
\text { Use Survey }\end{array}$} & \multirow[b]{2}{*}{ Model } & \multirow[b]{2}{*}{1975} & \multirow[b]{2}{*}{1995} & \multirow[b]{2}{*}{2000} \\
\hline & 1963 & 1967 & 1972 & & & & \\
\hline I & & & & $\begin{array}{l}A \\
B\end{array}$ & $\begin{array}{l}18,962 \\
19,240\end{array}$ & $\begin{array}{l}32,894 \\
33,487\end{array}$ & $\begin{array}{l}36,286 \\
36,719\end{array}$ \\
\hline II & & & & $\begin{array}{l}\text { A } \\
B\end{array}$ & $\begin{array}{l}18,962 \\
19,240\end{array}$ & $\begin{array}{l}30,120 \\
30,773\end{array}$ & $\begin{array}{l}31,888 \\
32,466\end{array}$ \\
\hline I IA & & & & $\begin{array}{l}\text { A } \\
B\end{array}$ & $\begin{array}{l}18,962 \\
19,240\end{array}$ & $\begin{array}{l}29,396 \\
30,164\end{array}$ & $\begin{array}{l}32,466 \\
32,784\end{array}$ \\
\hline I I I & 8,853 & 11,318 & 14,598 & $\begin{array}{l}\mathrm{A} \\
\mathrm{B}\end{array}$ & $\begin{array}{l}18,962 \\
19,240\end{array}$ & $\begin{array}{l}27,570 \\
27,603\end{array}$ & $\begin{array}{l}28,218 \\
27,962\end{array}$ \\
\hline IV & & & & $\begin{array}{l}\text { A } \\
\text { B }\end{array}$ & $\begin{array}{l}18,962 \\
19,240\end{array}$ & $\begin{array}{l}18,673 \\
18,181\end{array}$ & $\begin{array}{l}19,444 \\
18,619\end{array}$ \\
\hline $\begin{array}{r}\text { Hirst } \\
\text { Data }\end{array}$ & & & & $\begin{array}{l}\text { A } \\
\text { B }\end{array}$ & $\begin{array}{l}17,091 \\
17,762\end{array}$ & $\begin{array}{l}31,057 \\
31,992\end{array}$ & $\begin{array}{l}33,509 \\
34,021\end{array}$ \\
\hline
\end{tabular}


Table 1.2. Percent Distribution of Light Trucks by Major Use

\begin{tabular}{|c|c|c|c|c|c|c|}
\hline \multicolumn{4}{|c|}{ Truck Inventory and Use Survey } & \multicolumn{3}{|c|}{ Projections } \\
\hline Major use & 1963 & 1967 & 1972 & 1975 & 1995 & 2000 \\
\hline Personal & 34.7 & 44.8 & 53.4 & 56.1 & 59.3 & 60.8 \\
\hline For hire & 1.3 & 0.6 & 0.6 & 0.6 & 0.6 & 0.5 \\
\hline $\begin{array}{c}\text { Services and } \\
\text { utilities }\end{array}$ & 9.0 & 8.5 & 10.2 & 10.4 & 9.8 & 9.4 \\
\hline $\begin{array}{l}\text { Wholesale and } \\
\text { retail }\end{array}$ & 10.4 & 8.5 & 6.1 & 6.3 & 5.9 & 5.6 \\
\hline $\begin{array}{l}\text { Manufacturing } \\
\text { and mining }\end{array}$ & 2.7 & 1.7 & 1.5 & 1.5 & 1.4 & 1.4 \\
\hline Construction & 9.7 & 8.3 & 6.9 & 6.8 & 6.2 & 5.9 \\
\hline Agriculture & 29.6 & 23.6 & 20.1 & 20.1 & 18.6 & 18.0 \\
\hline $\begin{array}{l}\text { Forestry and } \\
\text { lumber }\end{array}$ & 1.0 & 1.0 & $0 . \tilde{5}$ & 0.5 & 0.5 & 0.5 \\
\hline (ither & 1.6 & 3.6 & 1.2 & 1.2 & 1.2 & 1.2 \\
\hline
\end{tabular}


Table 1.3. Parameters for scenarios

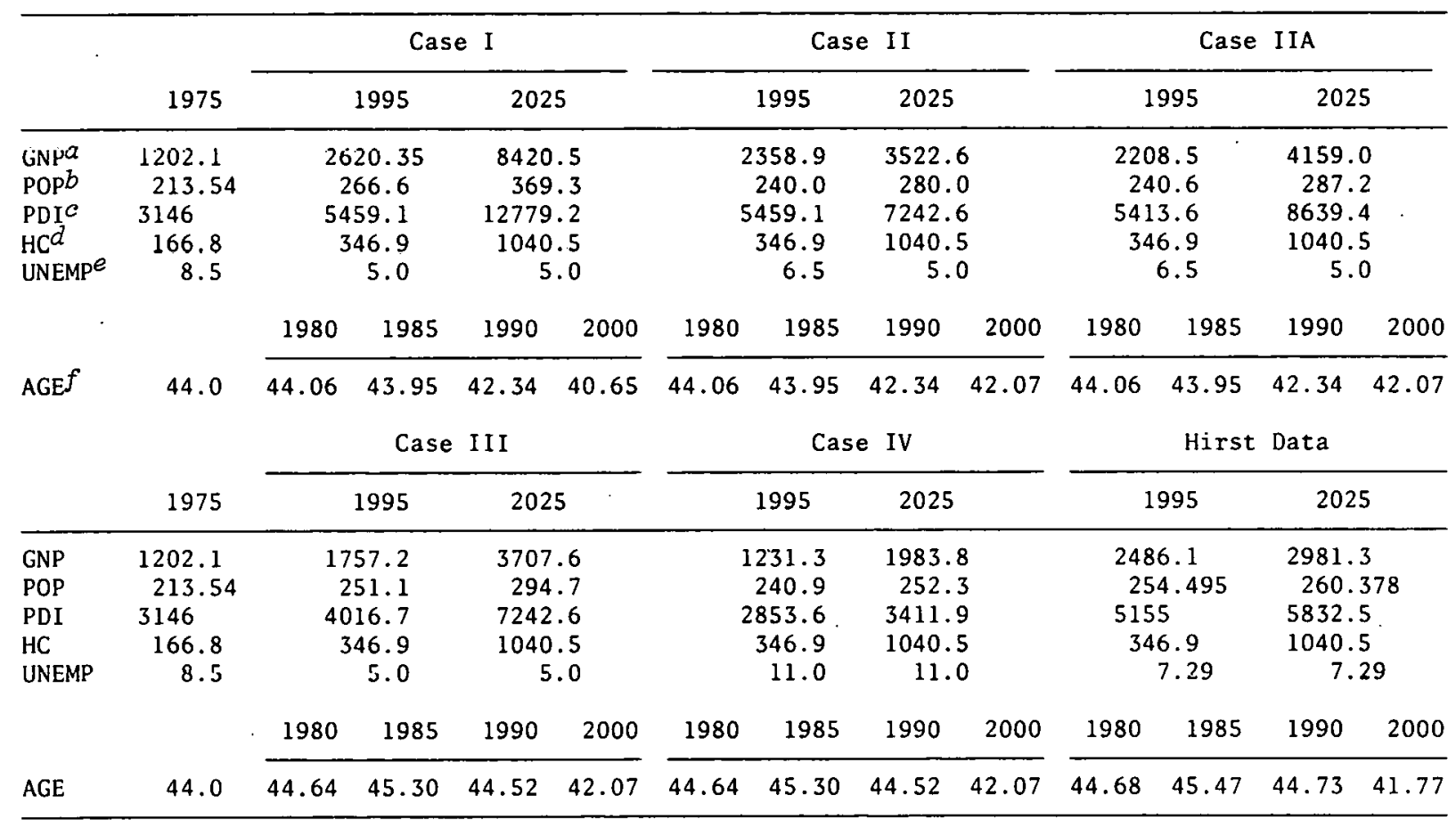

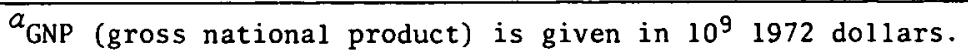

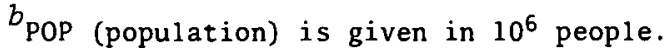

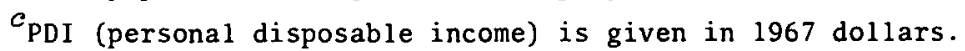

$d_{\mathrm{HC}}$ (consumer price index for housing) is given in 1967 dollars and is extrapolated from historical data on basis of average growth for the period 1963-1975.

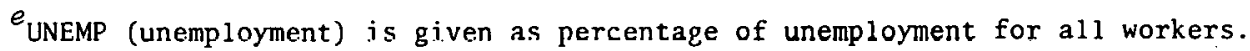

$f_{\text {AGE }}$ is the percent of population between the ages of 15 and 45 ; i.e., $15<x<45$.

Sources: Unempluyment data - David Curry, et al., Transportation in America's Future: Potential for the Next Half Century, prepared by Standford Research Institute for the U.S. Department of Transportation, DOT-TPI-20-77-21, June 1977; Age data - Statistical Abstracts of the United States, 1977, U.S. Department of Commerce, Bureau of the Census, Washington, D.C., 1977; Lindsey-Kaufman Co., Projection of Light Truck Population to Year 2025, ORNL/Sub-78/14285/1, Oak Ridge National Laboratory, Oak Ridge, Tenn., 1978; R. H. Goshorn, Socio-Economic Factors Affecting Household Formation and Housing Size in the United States, Oak Ridge National Laboratory, December 1977. (Computer print-out made available by E. Hirst of ORNL.) 
THIS PAGE

\section{WAS INTENTIONALLY \\ LEFT BLANK}




\section{DISCUSSION OF THE ORNL FORECASTS}

The forecasts are based on two models: A and B. Model A first estimates the number of light trucks and cars together and then applies a share's submodel to generate the forecast of light trucks. (The reasoning behind this approach is that light trucks can be considered as substitutes for cars.) Mode1 B estimates the number of cars and light trucks separately and yields the number of vehicles as a sum of the estimates. The forecasts generated by these two models (based on the scenarios detailed in Table 1.3) are remarkably close. With the exception of the latter years in Case IV, the difference between the two models rarely exceeds $2 \%$.

The model forecasts of light truck inventories are considerably lower than those of certain industry experts, the Lindsey-Kaufman Company in particular. Unfortunately, the derivation of Lindsey-Kaufman forecasts is not sufficiently quantitative to determine the source of the discrepancy. One can only surmise that the discrepancy is primarily due to a subjective evaluation of future and present societal attitudes as they affect the purchase of light trucks (other than the degree to which they are reflected in the other variables, these attitudes are implicitly assumed to remain invariant in the models because there is no explanatory variable which explicitly captures them).

The most dramatic differences between the models and Lindsey-Kaufman forecasts in the growth rate of light trucks manifest themselves in the years 1975-1980.

\begin{tabular}{llcl} 
& \multicolumn{2}{c}{ Light trucks $\times 10^{3}$ (in 1980) } \\
\cline { 2 - 4 } & Mode1 A & Mode1 B & L-K \\
\hline Case I & 22,477 & 22,873 & $29,500^{a}$ \\
Case II & $21,87.6$ & 22,280 & $28,00^{a}$ \\
Case IIA & 21,843 & 22,245 & $28,000^{a}$ \\
Case III & 21,558 & 21,864 & $28,000^{a}$ \\
Case IV. & 19,379 & 19,684 & $26,000^{a}$ \\
Hirst Data & 22,583 & 22,834 & \\
\hline \multicolumn{4}{c}{$a_{\text {Read from }}$ graph. }
\end{tabular}


The economic forecasts in the Lindsey-Kaufman (L-K) study do not appear of themselves to be sufficient justification for the explosive light truck growth forecasted by L-K. If such growth does occur, it must be attributed to shifts in consumer preference which had not totally manifested themselves by 1976. [The number of 1 ight trucks $\left(20,163 \times 10^{3}\right)$ calculated on the basis of a light truck to all truck ratio of 0.74 to 1.0 , and total truck estimate of $27,130 \times 10^{3}$ by the Motor Vehicle Manufacturers Association ${ }^{5}$ is close to the model projections documented herein.]

The plausibility of the forecasts generated by the models can further be evaluated on several grounds.

1. Models A and B showed surprising consistency with one another.

2. The Federai Highway Administration has forecast the car per person ratio to be 0.54 car per person in 1990. Cases I, II, IIA, and III yield ratios in the range from 0.549 car per person to 0.561 car per person for 1990. (To be sure, Case IV forecasts about 0.47 car per person, but this is not surprising in view of the dismal economic scenario applied in this case.) The Hirst Data yield a ratio of 0.572 .

3. In terms of historical trends, one would expect a car sales per truck sales ratio between $9: 1$ and $3: 1$, probably somewhat toward the lower end. The forecasts generated by the ORNL models are not inconsistent with these expectations. Again, Case IV is the most aberrant.

If one assumes the 1961 to 1974 average implicit retirement rates of 0.074 and 0.051 for cars and trucks respectively, use of the equations car sales (1975 through 2000) $=\sum_{i=1975}^{1999}[C(i+1)-C(i)+0.074 C(i)]$, truck sales $\left(1975\right.$ through 2000) $=\sum_{i=1975}^{1999}[T(i+1)-T(i)+0.051 T(i)]$, 
where

$$
\begin{aligned}
& \dot{C}(i)=\text { car inventory in year } i, \\
& T(i)=\text { light truck inventory in year } i,
\end{aligned}
$$

results in the cumulative car sales per truck sales ratios (1975-2000) found in columns 2 and 3 of the table below. The rates 0.069 and 0.059

\begin{tabular}{|c|c|c|c|c|}
\hline & \multicolumn{4}{|c|}{ Car sales per truck sales ratio ${ }^{a}$} \\
\hline & \multicolumn{2}{|c|}{$\begin{array}{c}\text { Retirement rates } \\
0.074,0.051^{b}\end{array}$} & \multicolumn{2}{|c|}{$\begin{array}{c}\text { Retirement rates } \\
0.069,0.059^{C}\end{array}$} \\
\hline & Model A & Model B & Model A & Model B \\
\hline $\begin{array}{l}\text { Case I } \\
\text { Case I I } \\
\text { Case IIA } \\
\text { Case III } \\
\text { Case IV } \\
\text { Hirst Data }\end{array}$ & $\begin{array}{l}5.85 \\
5.93 \\
5.89 \\
6.73 \\
8.61 \\
5.76\end{array}$ & $\begin{array}{l}5.82 \\
6.12 \\
5.85 \\
6.71 \\
9.00 \\
5.71\end{array}$ & $\begin{array}{l}5.01 \\
5.02 \\
4.99 \\
5.66 \\
6.99 \\
4.92\end{array}$ & $\begin{array}{l}4.96 \\
5.17 \\
4.94 \\
5.60 \\
7.24 \\
4.87\end{array}$ \\
\hline \multicolumn{5}{|c|}{$\begin{array}{l}{ }_{\text {Estimates are highly dependent on the assumed retirement }} \\
\text { rate. For example, an equal retirement rate for both cars and } \\
\text { trucks yields a car sales per truck sales ratio of } 4.5: 1 \text { for } \\
\text { Case I, model A. } \\
b \text { Average implicit retirement rates for } 1961 \text { to } 1974 . \\
{ }^{c} \text { Average implicit retirement rates for } 1970 \text { to } 1976 .\end{array}$} \\
\hline
\end{tabular}
yield the ratios in the last two columns.

\begin{tabular}{lcc}
\hline & \multicolumn{2}{c}{ Retirement rates } \\
\cline { 2 - 3 } Year & Light trucks & Cars \\
\hline 1964 & 0.035 & 0.070 \\
1965 & 0.049 & 0.089 \\
1966 & 0.057 & 0.089 \\
1967 & 0.052 & 0.068 \\
1968 & 0.059 & 0.079 \\
1969 & 0.066 & 0.085 \\
1970 & 0.047 & 0.059 \\
1971 & 0.041 & 0.065 \\
1972 & 0.038 & 0.063 \\
1973 & 0.070 & 0.078 \\
1974 & 0.088 & 0.084 \\
1975 & 0.076 & 0.067 \\
1976 & 0.056 & \\
\hline
\end{tabular}


On the basis of the car sales per truck sales ratios calculated above and shown in the tables below, one might suspect that the models underestimate somewhat the number of light trucks for the short run and that the L-K projections overestimate this number.

\begin{tabular}{lc}
\hline Year & Car sales per truck sales ratio \\
\hline 1963 & 8.502 \\
1964 & 7.923 \\
1965 & 7.995 \\
1966 & 7.159 \\
1967 & 7.208 \\
1968 & 6.811 \\
1969 & 6.382 \\
1970 & 6.063 \\
1971 & 6.161 \\
1972 & 5.214 \\
1973 & 4.467 \\
1974 & 3.924 \\
1975 & 4.104 \\
1976 & 3.707 \\
\hline
\end{tabular}

\begin{tabular}{lc}
$\begin{array}{r}\text { Car sales per } \\
\text { truck sales ratio }\end{array}$ & $\begin{array}{r}\text { Implicit inventory of light trucks in } 1980 \\
\text { at } 6 \% \\
\text { annual retirement rate }\left(10^{3}\right)^{*}\end{array}$ \\
\hline $1: 1$ & 53.82 \\
$1.5: 1$ & 41.08 \\
$2.0: 1$ & 34.72 \\
$2.5: 1$ & 30.90 \\
$3.0: 1$ & 28.35 \\
$3.5: 1$ & 26.53 \\
$4.0: 1$ & 25.17 \\
$4.5: 1$ & 24.11 \\
$5.0: 1$ & 2.3 .26 \\
\hline
\end{tabular}

Car inventory forecasts of model B (Case I) and car retirement rates of $7 \%$ annually. 
Clearly use of the minimum $1963-1976$ car sales per truck sales ratio would result in an estimate of about 25-26 $\times 10^{6}$ light trucks in 1980. An estimate more consistent with 1974-1976 trends would seem to be $24-25 \times 10^{6}$ light trucks. *

4. Another means of evaluating the plausibility of the forecasts is to investigate the light truck per person ratio.

\begin{tabular}{|c|c|c|c|}
\hline & \multicolumn{3}{|c|}{ Light truck per person ratio ${ }^{a}$ (1995) } \\
\hline & Mode 1 A & Model B & $\mathrm{L}-\mathrm{K}$ \\
\hline Case I & 0.120 & 0.122 & \\
\hline Case II & 0.123 & 0.126 & 0.16 \\
\hline Case IIA & 0.122 & 0.126 & 0.14 \\
\hline Case III & 0.126 & 0.109 & \\
\hline Case IV & 0.077 & 0.075 & \\
\hline Hirst Data & 0.123 & 0.127 & \\
\hline
\end{tabular}

$a_{\text {Historically, this ratio has varied between }}$ 0.0450 and 0.0876 (1960 to 1974 ).

\begin{tabular}{lc}
\hline Year & Light truck per person ratio \\
\hline 1961 & 0.045 \\
1962 & 0.047 \\
1963 & 0.047 \\
1964 & 0.052 \\
1965 & 0.054 \\
1966 & 0.057 \\
1967 & 0.060 \\
1968 & 0.062 \\
1969 & 0.065 \\
1970 & 0.068 \\
1971 & 0.071 \\
1972 & 0.075 \\
1973 & 0.082 \\
1974 & 0.088 \\
\hline
\end{tabular}

\footnotetext{
Case $I$ is the scenario leading to the greatest number of both cars and trucks.
} 
For 1995 (Case IIA), the "best judgment" of the L-K report, the models and the $\mathrm{L}-\mathrm{K}$ forecast are reasonably close.

5. The percentage change in the inventory of light trucks for the years 1963-1976 is given in the following table.

\begin{tabular}{cc}
\hline Year & $\begin{array}{c}\text { Change in 1ight truck } \\
\text { inventory }(\%)\end{array}$ \\
\hline $1963-1964$ & 6.4 \\
$1964-1965$ & 7.0 \\
$1965-1966$ & 6.3 \\
$1966-1967$ & 5.8 \\
$1967-1968$ & 4.9 \\
$1968-1969$ & 5.6 \\
$1969-1970$ & 5.3 \\
$1970-1971$ & 5.8 \\
$1971-1972$ & 7.3 \\
$1972-1973$ & 9.2 \\
$1973-1974$ & 6.1 \\
$1974-1975$ & 4.8 \\
$1975-1976$ & 5.4 \\
\hline
\end{tabular}

If one assumes $20.0 \times 10^{6}$ light trucks in 1976, then according to what one believes to be a reasonable annual percentage change in the stock of light trucks, one arrives at the 1980 inventory projections as listed below; and again, reasonable estimates would seem to be between 24 and $26 \times 10^{6}$ light trucks.

\begin{tabular}{cc}
\hline $\begin{array}{c}\text { Annual change in } \\
\text { inventory }(\%)\end{array}$ & $\begin{array}{c}1980 \text { inventory of } \\
\text { light trucks }\left(10^{\kappa}\right)\end{array}$ \\
\hline 1.0 & 23.40 \\
4.5 & 23.85 \\
5.0 & 24.31 \\
5.5 & 24.78 \\
6.0 & 25.25 \\
6.5 & 25.79 \\
7.0 & 26.22 \\
7.5 & 26.71 \\
8.0 & 27.21 \\
8.5 & 27.72 \\
9.0 & 28.23 \\
9.5 & 28.75 \\
10.0 & 29.28 \\
\hline
\end{tabular}


In short, if light truck sales continue to increase at or somewhat above their historical maximum rate, a projected inventory of light trucks for 1980 would be about $28 \times 10^{6}$. A projected inventory of about $24 \times 10^{6}$ is in keeping with a more modest rate of growth, for instance, as realized in the period 1974-1976. Thus, the projections determined by the models may be conservative in the sense that the models were calibrated with data for the period 1963-1974. However, for the long term, it is difficult to determine whether the light truck market will sustain its recent high rate of growth or will level off.

The weakest point of the analysis is perhaps the partition of the total number of light trucks into major use categories. The algorithm to achieve this end was particularly simple: the 1972 partition was extrapolated on the basis of Table 34, p. 50 of Trucking Activity and Fuel Consumption (Table 2.1 of this report). The specific equations are given in the next section along with a more detailed justification. On the basis of cross-sectional state level data for 1972, the extrapolation scheme does seem unreasonable if one assumes the forecasts listed in Table 2.1.

of course, any forecast generated by a formal model depends on the conjectured scenario which drives the model. For this monograph, six such scenarios were selected and are detailed in Table 1.3. For Cases I, II, IIA, III, and IV, the data for GNP, POP; and PDI have been taken directly from the L-K document (GNP deflated to 1972 dollars, PD deflated to 1967 dollars). The unemployment statistics were determined from Curry et al., 11 and the AGE statistics were taken from the Statistical Abstract ${ }^{12}$ for the appropriate Census Bureau projections as detailed in L-K. The variable HC has been determined to grow at $3.7 \%$ per annum. The scenario "Hirst Data" is based on projections by Hirst. 10

The variables GNP, POP, PDI, and HC were interpolated in terms of constant growth for the periods 1975 to 1995, and 1995 to 2025; the variables UNEMP and AGE were interpolated linearly. 
Table 2.1. Growth Rates of GNP and Sector Outputs Used in the Trucking Projections

\begin{tabular}{|c|c|c|c|}
\hline & \multicolumn{3}{|c|}{ Average annual rate of growth } \\
\hline & $1972-1980$ & $1980-1990^{a}$ & $1972-1990$ \\
\hline Gross national product ${ }^{b}{ }^{\prime}$ & 3.1 & 2.9 & 3.0 \\
\hline Agricul ture & 3.3 & 2.5 & 2.9 \\
\hline Construction ${ }^{c}$ & 2.5 & 2.5 & 2.5 \\
\hline Manufacturing and mining ${ }^{c}$ & 3.5 & 3.2 & 3.3 \\
\hline Wholesale and retail trade ${ }^{c}$ & 4.1 & 2.4 & 3.1 \\
\hline Services and utilities ${ }^{c}$ & 3.8 & 2.7 & 3.2 \\
\hline For hire truckingd & 3.1 & 2.9 & 3.0 \\
\hline Personal truckingd & 4.9 & 4.0 & 4.4 \\
\hline
\end{tabular}

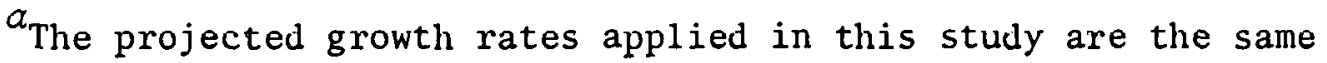
for 1980-1985 and 1985-1990.

$b_{\text {These growth rates are from the Data Resources Incorporated }}$ (DRI) economic projections provided Jack Faucett Associates by FEA.

${ }^{2}$ These growth rates are from the University of Maryland InputOutput projections adjusted to be compatible with the DRI GNP growth.

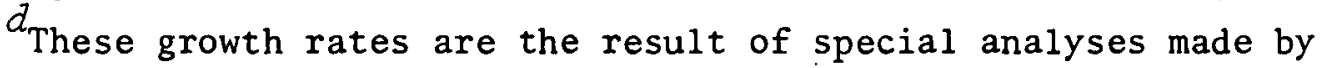
Jack Faucett Associates.

Source: Jack Faucett!Associates, Inc., Trucking Astivity and Fuel Consumption, 1973, 1980, 1985, and 1990, Chevy Chase, Md., July 1876, Table 34, p. 50 . 


\section{TECHNICAL ANALYSIS OF MODELS}

Two difficulties common to much of econometric analysis are immediately encountered in this attempt to forecast the number of 1 ight trucks. The first is that most economic indicators, as well as the number of light trucks, have historically exhibited steady growth and, therefore, simulation forecasts are apt to diverge from a heuristically feasible region. The second is that data are not available for the converitional explanatory variable - average light truck price - nor for a time series for light truck fuel economy. The results presented in this paper must be interpreted in light of these difficulties.

The first difficulty, that of predictions exceeding heuristically reasonable bounds, was dealt with by choosing a. logistic formulation for each of the models, a formulation which assures that the sum of light trucks and cars not exceed the population:

MODEL A

Stage 1: $\quad$ LNVEH $=\ln \left(\frac{\text { VEH/POP }}{1-V E H / P O P}\right)=f(P D I, H H S Z$, UNEMP, AGE, FP, $\ldots)$,

Stage 2: $\quad$ LSTSC $=\ln (\mathrm{T} / \mathrm{C})=\mathrm{g}(\mathrm{PDI}, \mathrm{HHSZ}, \mathrm{UNEMP}, \mathrm{AGE}, \mathrm{FP}, \ldots)$,

Stage 3: $\frac{T+C}{V E H}=1$

$$
\mathrm{T}=\{[\mathrm{g}(\mathrm{PDI}, \ldots)] /[1+\mathrm{g}(\mathrm{PDI}, \ldots)]\} \times \mathrm{VEH}
$$

The first stage of this model regresses a transformation of the sum of the number of light trucks and cars against the explanatory variables. The second stage develops the shares model, and the third stage uses the relationship $\mathrm{T}+\mathrm{C}=\mathrm{VEH}$ and the results of the first two stages to ca1culale lle sumber of liglil liucks.

In the estimation of the sharcs model, it would be desirable as well as conventional to include the ratio of prices (truck price to car 
price); however, all truck prices known to the author appear in disaggregated form in Automotive News, and the aggregation of these data was beyond the scope of this study. Similarly, light truck fuel economy appears not to be available in a time series, so that neither of these explanatory variables was used.

As mentioned previously, the implicit constraint in model $A$ is that the sum of light trucks and cars not exceed the population. Though this may appear to be an artificial constraint, the fact that the ratio VEH/POP stays well away from the asymptotic limit 1 in all the simulations indicates that the constraint has not been fully activated and is less artificial than may appear at first glance.

The second model, model $\mathrm{B}$, depends on a similar logistic formulation:

MODEL B

$$
\begin{aligned}
& \text { LNTRVEH }=\ln \left[\frac{\mathrm{T} / \mathrm{POP}}{1-(\mathrm{T}+\mathrm{C}) / \mathrm{POP}}\right]=\mathrm{f}(\mathrm{PDI}, \mathrm{HHSZ}, \mathrm{UNEMP}, \mathrm{AGE}, \mathrm{FP}, \ldots), \\
& \text { LNCVEH }=\ln \left[\frac{\mathrm{C} / \mathrm{POP}}{1-(\mathrm{T}+\mathrm{C}) / \mathrm{POF}}\right]=\mathrm{G}(\mathrm{PDI}, \mathrm{HHSZ}, \mathrm{UNEMP}, \mathrm{AGE}, \mathrm{FP}, \ldots) .
\end{aligned}
$$

This simultaneous system of equations can easily be solved for both $T$ and C. Moreover, it is easily seen (as long as $\mathrm{T}, \mathrm{C}>0$ ) that model B constrains $\mathrm{T}$ to be asymptotically smaller than would be determined by the formulation

$$
\ln \left(\frac{\mathrm{T} / \mathrm{POP}}{1-\mathrm{T} / \mathrm{POP}}\right)
$$

Mudel B is formulatcd as a stock adjustment model, which is aclually equivalent to a first-order autoregressive model. The heuristics for such a model are outlined below.

One first assumes that the economically stable equilibrium of LNTRVEH$^{*}(n)$ at time $n$ is given in terms of other explanatory variables,

$$
\operatorname{LNTRVEH}^{*}(n)=f(\operatorname{PDI}, \operatorname{HHSZ} \ldots)
$$


The number of light trucks, being a major durable capital good, cannot be expected to immediately adjust to equal the theoretical equilibrium; hence an adjustment process is postulated,

$$
\operatorname{LNTRVEH}(n)=\operatorname{LNTRVEH}(n-1)+\delta[\operatorname{LNTRVEH} *(n)-\operatorname{LNTRVEH}(n-1)] .
$$

Of course, one expects that the adjustment coefficient $\delta$ lies between 0 and 1 (i.e., $0<\delta<1$ ). The simultaneous solution of Eqs. (1) and (2) yields

$$
\operatorname{LNTRVEH}(n)=(1-\delta) \operatorname{LNTRVEH}(n-1)+\delta[f(\operatorname{PDI}, \mathrm{HHSZ}, \ldots)]
$$

The smaller the regression coefficient accompanying the lagged variable, the more rapid the implicit adjustment response.

The actual equations of models $A$ and $B$ are given below. The coefficients were estimated by ordinary least squares regression of national time series data. (The significance levels of the coefficients are included in parentheses.)

MODEL A

$$
\begin{aligned}
& \text { 1. } \begin{aligned}
& \text { LNVEH }=-18.60887239+3.31754182 \mathrm{LAGE}- \\
&(0.0001) \\
&+(0.0001) \\
&+ 0.88412928 \mathrm{LPDI}-0.04344654 \mathrm{LHHSZ} \\
&(0.0001)(0.1077) \\
&(0.0244)
\end{aligned} \\
& \mathrm{R}^{2}= 0.9995, \quad \mathrm{DW}=1.5073 .
\end{aligned}
$$

2. LSTSC $=-9.76902093+1.13262720 \mathrm{LAGE}+0.46539166 \mathrm{LPDI}$,

$$
(0.0001) \quad(0.0003) \quad(0.0001)
$$

$$
\mathrm{R}^{2}=0.9850, \quad \mathrm{DW}=2.0244 \text {. }
$$


MODEL B

1. $\mathrm{LNCVEH}=-14.74195127+2.36651560$ LAGE +0.74045065 LPDI

$$
(0.0003) \quad(0.0004) \quad(0.0004)
$$

$+0.27920896 \mathrm{LNCVEH} 1$, $(0.0818)$

$$
\mathrm{R}^{2}=0.9991 ; \quad \mathrm{DW}=1.8839 \text {. }
$$

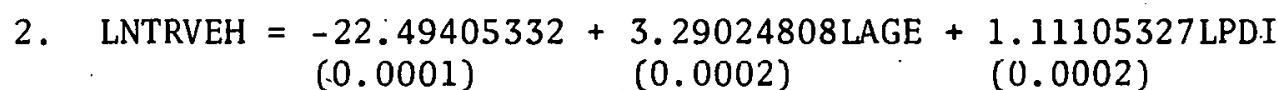

$+0,2.5989 .339$ INTRVEHI, $(0.0708)$

$$
\mathrm{R}^{2}=0.9988, \quad \mathrm{DW}=2.5365 \text {. }
$$

The residuals of models $A$ and $B$ are examined below.

MODEL A

Eq. 1. The DW statistic is inconclusive. ${ }^{13}$ The runs test ${ }^{14}$ did not indicate a significant correlation among the residuals [6 runs with a signs distribution of $(6,8)] .^{*}$

Eq. 2. The DW statistic indicates lack of first order autocorrelation. The runs test [ 7 runs with a sign distribution of $(5,9)]$ did not indicate a significant correlation among the residuals.

MODEL B

Eq. 1. The runs test [ 7 runs with a sign distribution of $(6,8)$ ] did not indicate a significant correlation among the residuals. The Durbin $\mathrm{K}_{2}$ statistic $^{15}$ is 0.0505 - inconclusive.

Eq. 2. The runs test [ 7 runs with a sign distribution of $(6,8)$ ] did not indicate a significant correlation among the residuals. The Durbin $K_{2}$ statistic is $1.0088^{\circ}$ - no significant correlation implied.

* The runs test counts the number of sign changes in the residuals and adds one. Thus, if the residuals had signs,,,,,$+--++-;$ the runs tests would be applied to 4 runs with a signs distribution of $(2,2)$. 
The variables are defined as follows:

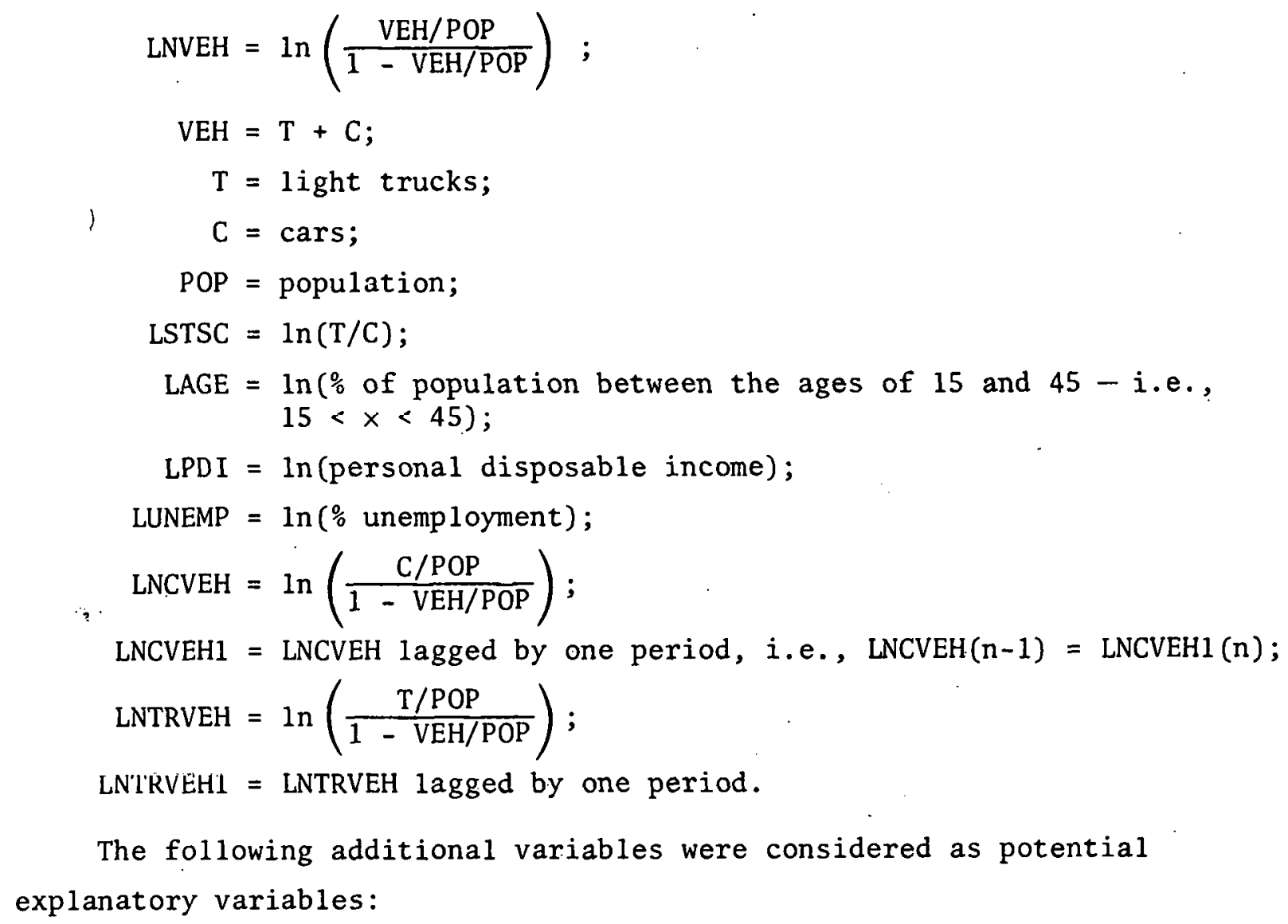

LNIRVEHI = LNTRVEH lagged by one period.

The following additional variables were considered as potential explanatory variables:

- gross national product

- average vehicle-miles per car

- average vehicle-miles per truck

- number of licensed drivers

- car fuel economy

- price of new cars

- price of gasoline

- retail-wholesale sales

- car sales

- light truck sales

- construction activity

Probably, the least intuitive of the explanatory variables is LAGE. This variable was chosen for inclusion as an explanatory variable because it was suspected that the ownership rate of vehicles by persons in this age bracket was higher than that by persons in other age brackets. The 
available data were insufficient to either confirm or refute this conjecture, and it is conceivable that the resultant correlation is spurious. However, when the variable LAGE was replaced by the natural logarithm of the percentage of the population between the ages of 15 and 65 , the explanatory variable lost its significance, even though the population in the 15 to 65 age bracket was monotonically increasing during this period (both numerically and relatively).

Since the L-K scenarios did not specify household size, an additional regression was run:

$$
\begin{aligned}
& \text { LNHHSZ }=-2.47111848+0.64867304 \text { I.HC }-0.03117339 \text { LUNEMP } ; \\
& (0.0001) \quad(0.0001) \quad(0.1047) \\
& \mathrm{R}^{2}=0.9877, \quad \mathrm{DW}=1.9561 \text {. }
\end{aligned}
$$

Runs test: 8 runs, sign distribution $(7,7)$ - no significant correlation implied.

The variables are defined to be

$$
\begin{aligned}
\text { LNHHSZ } & =\ln \left(\frac{\mathrm{HSF} / \mathrm{POP}}{0.5-\mathrm{HSE} / \mathrm{POP}}\right), \\
\text { HSE } & =\text { number of households }, \\
\text { LHC } & =\ln (\text { housing cost index). }
\end{aligned}
$$

The application of this equation to the simulation scenarios resulted in predicted household size of 2.62 to 2.64 for 1990 , consistent with Census Bureau predictions of 2.68 for forecast A, 2.60 for forecast B, and 2.61 for forecast $C$. A consistent interpretation of the regression equation could be that unemployment increases short-term household size by causing more people to share expenses, and that increased housing costs result in long-term reductions of family size.

To partition the total number of light trucks into major use categories, the growth rates for the respective sectors (which determined use) were applied to the 1972 distribution of light trucks and the subsequent 
results were normalized. This algorithm was later tested against 1972 cross sectional data with reasonable results: The test consisted of forming all two-fold combinations (pairs) of states and, for each combination, estimating the percentage of light trucks used primarily for retail-wholesale trade in the second state on the basis of both states' retail sales, construction contracts, and the relative number of light trucks used for both construction or retail-wholesale trade in the first state. Formally, let

$$
\begin{aligned}
C(i) & =\text { construction contracts in state } i, \\
r(i) & =\text { retail sales in state } i \\
L C(i) & =\text { light trucks used in construction state } i, \\
\operatorname{Lr}(i) & =\text { light trucks used in retail-wholesale trade state } i .
\end{aligned}
$$

If the proportion of each type of light truck is calculated as

$$
\begin{aligned}
& \operatorname{nLC}(i)=\operatorname{LC}(i) /[\operatorname{LC}(i)+\operatorname{Lr}(i)], \\
& n \operatorname{Lr}(i)=\operatorname{Lr}(i) /[\operatorname{LC}(i)+\operatorname{Lr}(i)]=1-n L C(i),
\end{aligned}
$$

then the error of the extrapolation $D(i, j)$ can be calculated as

$$
D(i, j)=n \operatorname{Lr}(j)-\frac{n \operatorname{Lr}(i)[r(j) / r(i)]}{n \operatorname{Lr}(i)[r(j) / r(i)]+n L C(i)[C(j) / C(i)]} .
$$

For $i<j$, the mean and standard deviation of the values $D(i, j)$ werc calculated:

$$
\begin{aligned}
& \mu(D)=-0.00316, \\
& \sigma(D)=0.13307 .
\end{aligned}
$$

For the observed values of $n L r$, the mean and standard deviation were determined to be

$$
\begin{aligned}
& \mu(\mathrm{nLr})=0.64880, \\
& \sigma(\mathrm{nLr})=0.09082 .
\end{aligned}
$$


(Figures 3.1 and 3.2 show the frequency distribution of $D$ and $n L r$ with the same scale for the abscissa.)

Although the distribution of the error $D$ has mean nearly zero, it is not as tightly concentrated as would be desirable. This suggests of course that though the partitioning of light trucks into major use categories is not unreasonable, it must be viewed with healthy caution.

The behavior and sensitivity to perturbations of the initial values and hypotheses of the models can be inferred by approximating these models by a linearized version. Consider the sequence of vectors $\{x(n), n-0,1\}$ defined by

$$
X(n)=\left[\begin{array}{ll}
\text { LNTRVEH } & (\mathrm{n}-1) \\
\text { LNCVEH } & (\mathrm{n}-1) \\
\text { LNVEH } & (\mathrm{n}) \\
\text { LSTSC } & (\mathrm{n}) \\
\text { LHHSZ } & (\mathrm{n}) \\
\text { LAGE } & (\mathrm{n}) \\
\text { LPDI } & (\mathrm{n}) \\
\text { LUNEMP } & (\mathrm{n})
\end{array}\right]=\operatorname{AX}(\mathrm{n}-1)+B \text {, }
$$

with additional boundary conditions

$$
X\left(U^{\prime}\right)=\left[\begin{array}{ll}
\text { LNTRVEH } & (-1) \\
\text { LNCVEH } & (-1) \\
\text { LNVEH } & (\cup) \\
\text { LSTSC } & (0) \\
\text { LHHSZ } & (0) \\
\text { LAGE } & (0) \\
\text { LPU I } & (0) \\
\text { LUNEMP } & (0)
\end{array}\right]
$$




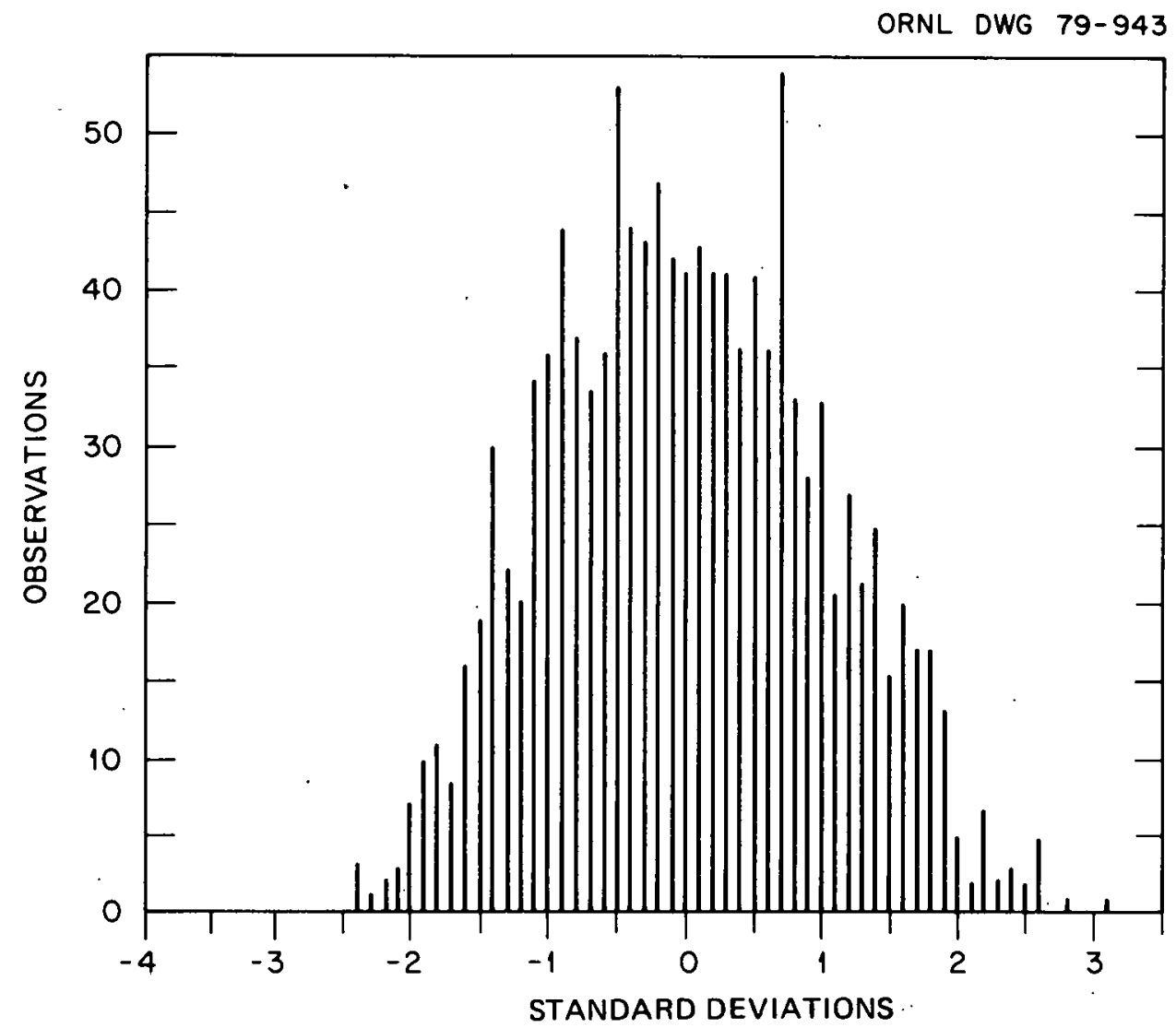

Fig. 3.1. Frequency Distribution of $D(i, j)$ for 1972.

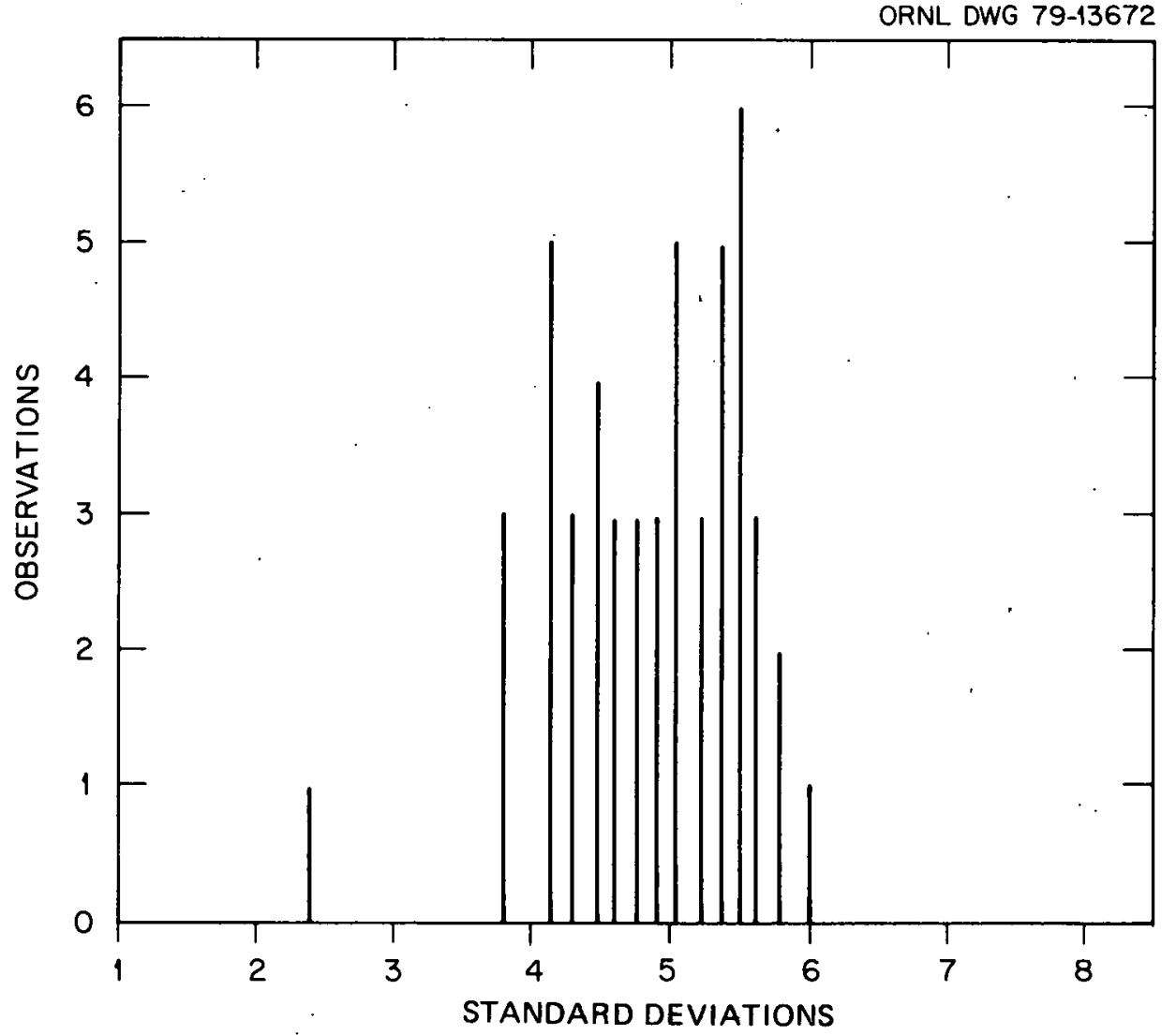

Fig. 3.2. Frequency Distribution for nLr for 1972. 


$$
\begin{aligned}
& \text { matrix } A=\left[\begin{array}{llllllll}
0.2 & 0 & 0 & 0 & 0 & 3.2 & 1.1 & 0 \\
0 & 0.2 & 0 & 0 & 0 & 2.3 & 0.7 & 0 \\
0 & 0 & 0 & 0 & -0.5 & 3.3 & 0.8 & -.04 \\
0 & 0 & 0 & 0 & 0 & 1.1 & 0.4 & 0 \\
0 & 0 & 0 & 0 & f(n) & 0 & 0 & 0 \\
0 & 0 & 0 & 0 & 0 & 1 & 0 & 0 \\
0 & 0 & 0 & 0 & 0 & 0 & 1 & 0 \\
0 & 0 & 0 & 0 & 0 & 0 & 0 & 1
\end{array}\right] \text {, } \\
& \text { vector } B=\left[\begin{array}{c}
-h_{1} \\
-b_{2} \\
-b_{3} \\
b_{4} \\
0 \\
0 \\
b_{7} \\
0
\end{array}\right] .
\end{aligned}
$$

(The coefficients of the matrix $A$ have been chosen to be the first two significant digits of the coefficients of the respective estimated equations. The function $f$ is a monotonically increasing function with upper bound 1 and lower bound >0.9 with $\left\{\prod_{n=1}^{\infty} f(n)\right\}$ convergent.)

It is not hard to see that this system behaves "in the large" much as models $A$ and $B$. Iterative calculations yield

$$
X(n)=A^{n} X(0)+\left(\sum_{i=1}^{n-1} A^{i}\right) B
$$

and 


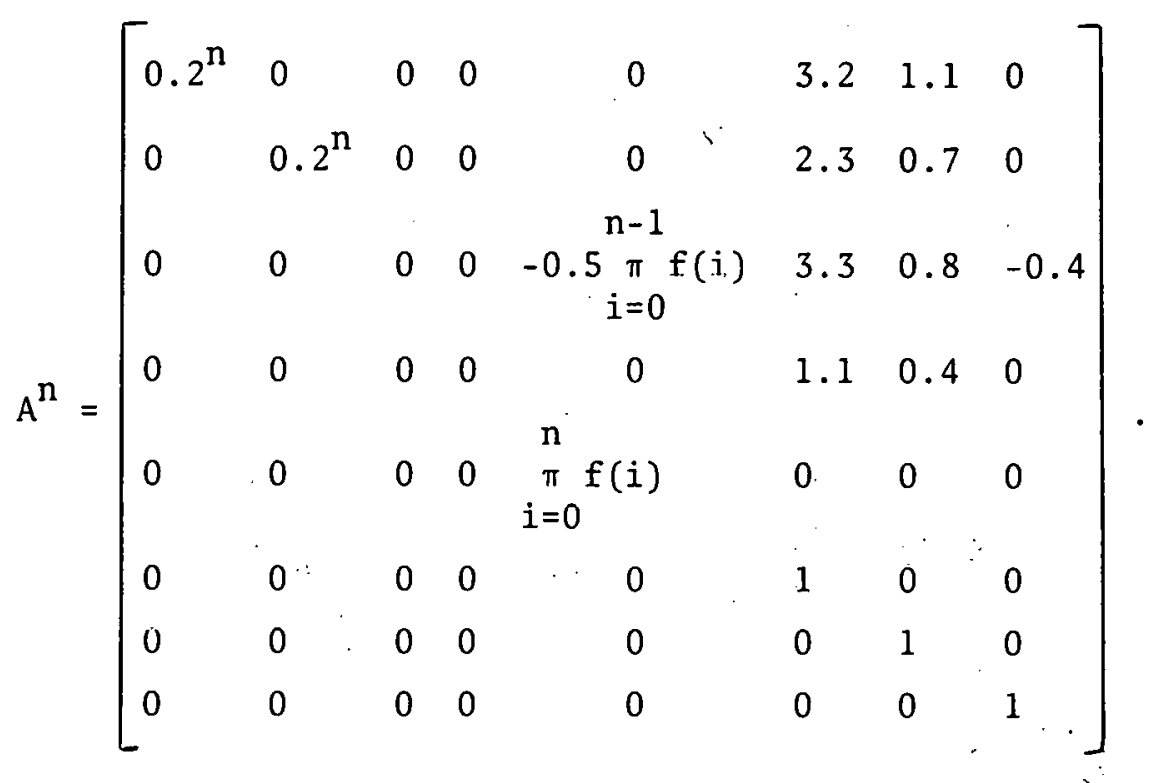

Thus the following results can be deduced from this analysis.

1. $\quad \operatorname{LNTRVEH}(\mathrm{n})=\frac{\mathrm{T}(\mathrm{n}) / \mathrm{POP}(\mathrm{n})}{1-[\mathrm{T}(\mathrm{n})+\mathrm{C}(\mathrm{n})] / \mathrm{POP}(\mathrm{n})}$

is globally stable with regard to its initial value. Essentially this means that a perturbation in the original number of light trucks for all physically realizable stock adjustment models will not affect the longrange light truck forecasts.

In fact,

$\frac{\partial[\mathrm{T}(\mathrm{n})]}{\partial[\mathrm{T}(\mathrm{o})]}=0\left\{(0.2)^{\mathrm{n}} \frac{\mathrm{T}(\mathrm{n})}{\mathrm{T}(\mathrm{o})}\right\}^{*}$ for model B,

$\frac{\partial[T(n)]}{\partial[T(0)]}=0 \quad$ for model $A$

$\frac{\partial[T(n)]}{\partial[T(0)]}=0(0.2)^{n} \frac{T(n)}{T(0)}$ is defined to mean that there exits a constant $L$ such that, for $N$ sufficiently large and $n>N$, $\left|\frac{\partial[T(n)]}{\partial[T(0)]}\right|<L(0.2)^{n} \frac{T(n)}{T(0)}$. 
2. A similar stability result holds for LNCVEH.

3. Perturbations in the initial values of LAGE and LPDI will affect both LNTRVEH and LNCVEH, and the magnitude of the effect is determined by the product of the size of the perturbation by the respective regression coefficient.

Specifically,

$$
\begin{aligned}
& \frac{\partial[T(n)]}{\partial[\operatorname{AGE}(0)]}=0\left\{\frac{T(n)}{\operatorname{AGE}(0)}\right\} \text { for model } B, \\
& \frac{\partial[T(n)]}{\partial[\operatorname{PDI}(0)]}=0\left\{\frac{T(n)}{\operatorname{PDI}(0)}\right\} \text { for model } B .
\end{aligned}
$$

Similar equalities hold for cars. Sensitivity of model A to the initial values requires a considerably more complicated expression but has the same flavor.

4. The effects of misspecification of the models insofar as the regression coefficients are concerned are also easily calculated. of particular interest is

$$
\frac{\partial[\mathrm{T}(\mathrm{n})]}{\partial \mathrm{b}_{7}}
$$

So long as the ratio

$$
\text { C (1i) / FOF (ii) }
$$

remains bounded away from one, it is easy to see that

$$
\frac{\partial[T(n)]}{\partial b_{7}}=0\{(n-1) T(n)\}
$$

for mode1 B. This result indicates that the number of light trucks is particularly sensitive to the growth of PDI. 
5. The values of LNTRVEH, LNCVEH, and LNVEH are dependent not only on the initial and terminal values of PDI but also on the path between these points. The path used for this model was determined by the end points and constant growth.

In summary, this technical analysis indicates that the models formulated here are not unreasonable. In the long run, they are insensitive to the initial number of cars or light trucks. However, they are sensitive to the population growth and particularly sensitive to the expected behavior of personal disposable income. 
THIS PAGE

\section{WAS INTENTIONALLY \\ LEFT BLANK}




\section{DISCUSSION OF MODEL REFINEMENTS, . IMPROVEMENTS, AND SHORTCOMINGS}

Several avenues for improvements of the model immediately suggest themselves, yet almost all depend on the greater availability and accuracy of light truck data than is presently at hand.

1. The actual number of light trucks used to generate the regression coefficients in this report. was estimated from total truck inventory data from the 1975 Automobile Fac.ts and Figures and the ratio of 1 ight trucks per all trucks data from the 1963, 1967, and 1972 Truck Inventory and Use Surveys. These latter ratios were interpolated linearly for intervening years. Two sources of error are possible. The lesser one is that due to linear interpolation. The other is that the Automobile Facts and Figures' data are revised annually, sometimes significantly. (The sensitivity of the coefficients to the light truck inventory data has not yet been investigated.)

With the processing of the state-level Polk data for automobiles and light trucks, it should be possible to refine the regression analysis by cross-sectional time series analysis on more timely data as well as specific major end use analyses.

2. The variable AGE was interpolated. Other sources provide these data in the format appropriate to this study and hence obviate the necessity of interpolation. Such data should be used.

3. A case can justifiably be made that model $B$ is a simultaneous equation model and should more appropriately be estimated by two-stage least squares or similar approach. How such an approach would affect the results is unknown at the present time. 
THIS PAGE

WAS INTENTIONALLY

LEFT BLANK 


\section{CONCLUSIONS}

There seems little doubt that the number of light trucks will increase in the near future, regardless of the measure used (actual numerical count, trucks per person, or truck per car ratio). Moreover, the general concensus seems to be that the light truck per person ratio will stabilize sometime in the next one to three decades. The time and level of truck per person ratio at which this stabilization will take place is an issue subject to less unanimity. Models A and B suggest that unless the economy slows, this stabilization will not occur before the year 2000. Certain of the L-K forecasts suggest stabilization at 0.14 truck per person by the year 1985 (Case IIA). For this same case, models $A$ and $B$ forecast 0.131 truck per person and 0.133 truck per person, respectively, in the year 2000 .

There are, of course, many contingencies which neither models $A$ and B nor the L-K forecasts consider: wholesale electrification of motor vehicles or abolishment of private ownership of vehicles, to name two. Hence, the forecasts are general indicators at best. Models A and B are open to critical review and for delicate and detailed policy questions these models should be supplemented by further analyses, both quantitative and qualitative. Attention should be directed to the plausibility of the forecasting scenarios and also to the reliability of the historical data which form the basis of any forecasts. Additional analytical work might involve time-series cross-sectional analysis as well as modeling each of the major light truck uses explicitly. Unfortunately, the quality of the data available for this study is such that even a sophisticated model may yield no additional insight. 
APPENDIX A

AUTOMOBILE FORECASTS 


\section{REFERENCES}

1. Linsey-Kaufman Company, Projection of Light Truck Population to Year 2025, ORNL/Sub-78/14285/1, Oak Ridge National Laboratory, Oak Ridge, Tenn., October 1978.

2. U.S. Department of Commerce, Bureau of the Census, $1 \ddot{y} 72$ Census of Transportation, "Truck Inventory and Use Survey - United States Summary," Series TC72-T52, Washington, D.C., 1973.

3. U.S. Department of Commerce, Bureau of the Census, 1963 Census of Transportation, "Truck Inventory and Use Survey - United States Summary", Series TC63(A)-T61, Washington, D.C., April 1965.

4. U.S. Department of Commerce, Bureau of the Census, 1967 Census of Transportation, "Truck Inventory and Use Survey - United States Summary", Series TC67(A)-T61, Washington, D.C., June 1969.

5. Motor Vehicle Manufacturers Association of the U.S., Inc., 1975 Automobile Facts and Figures, p. 24, Detroit, 1975.

6. Automotive News, 1965 Almanac Issue, April 30, 1973, pp. 16, 36; Automotive News, 1975 Almanac Issue, April 23, 1975, p. 4: Slocum Publishing Co., Inc., Detroit.

7. Business Week, July 11, 1977.

8. W. F. Gay, Energy Statistics, U.S. Department of Transportation, p. 137, Washington, D.C., 1975.

9. Jack Faucett Associates, Inc., Trucking Activity and Fuel Consumption 1973, 1980, 1985, and 1990, Table 35, p.' 59, Chevy Chase, Md., July. 1976.

10. R. H. Goshorn, Socio-Fronomic Factors Affecting Household Formation and Housing Size in the United States, Oak Ridge National Laboratory, December 1977. Unpublished paper. (Computer print-out made available by Eric Hirst of ORNL.)

11. David Curry et al., Transportation in America's Future: Potential for the Next Half Century, prepared by Standford Research Institute 
for the Department of Transportation, DOT-TPI-20-77-21, June 1977.

12. U.S. Department of Commerce, Bureau of the Census, Statistical Abstract of the United States 1977, Washington, D.C., 1977.

13. J. Johnston, Econometric Methods, McGraw-Hi11, New York, 1972.

14. N. Draper and H. Smith, Applied Regression Analysis, John Wiley and Sons, Inc., New York, 1966.

15. J. Durbin, "l'esting for Serial Correlation in Least-Squares Regression When Some of the Regressor's Are Lagged Dependent Variablos," Econometrica 38: 410-421, May 1970. 


\section{PAGES A-1 to $\underline{A-2}$ WERE INTENTIONALLY LEFT BLANK}


A-3

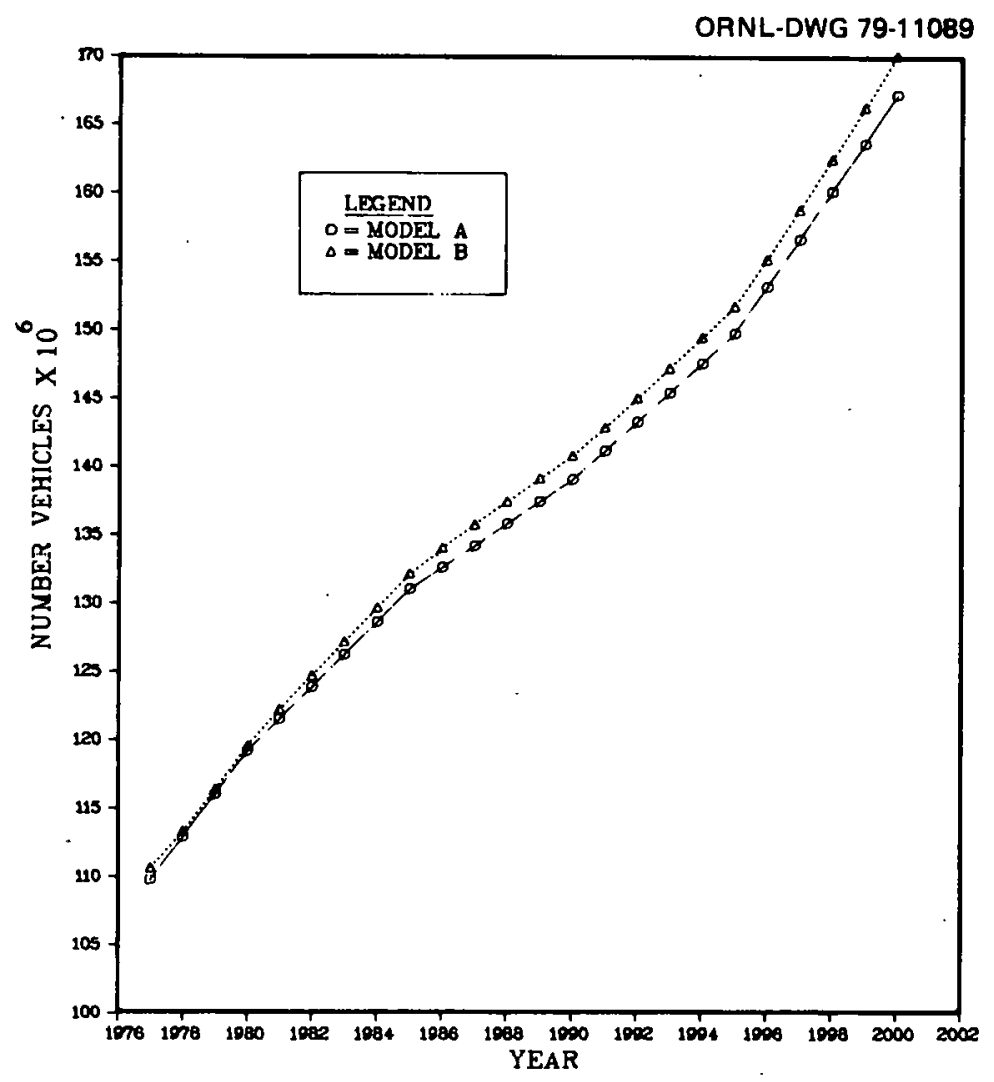

Fig. A.1. Automobile Forecast - Case I.

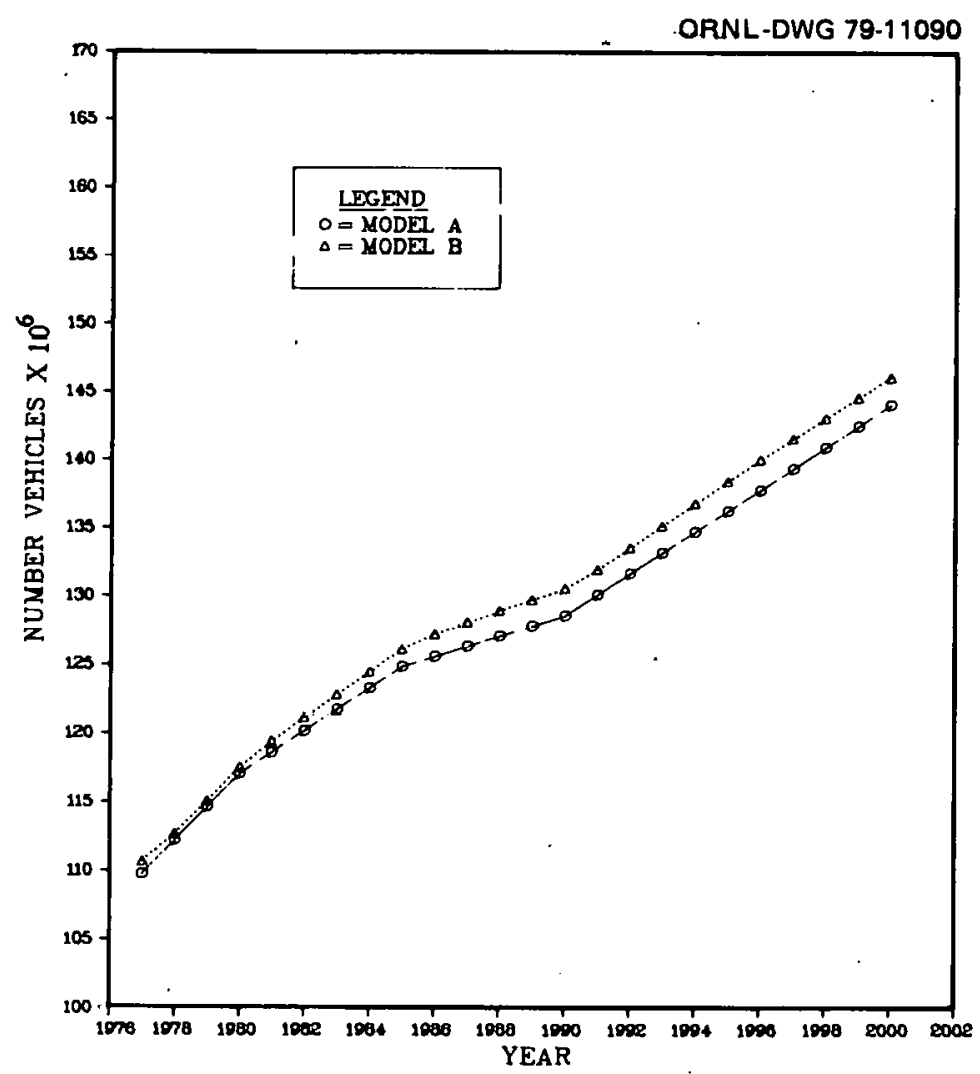

Fig. A.2. Automobile Forecast - Case II. 


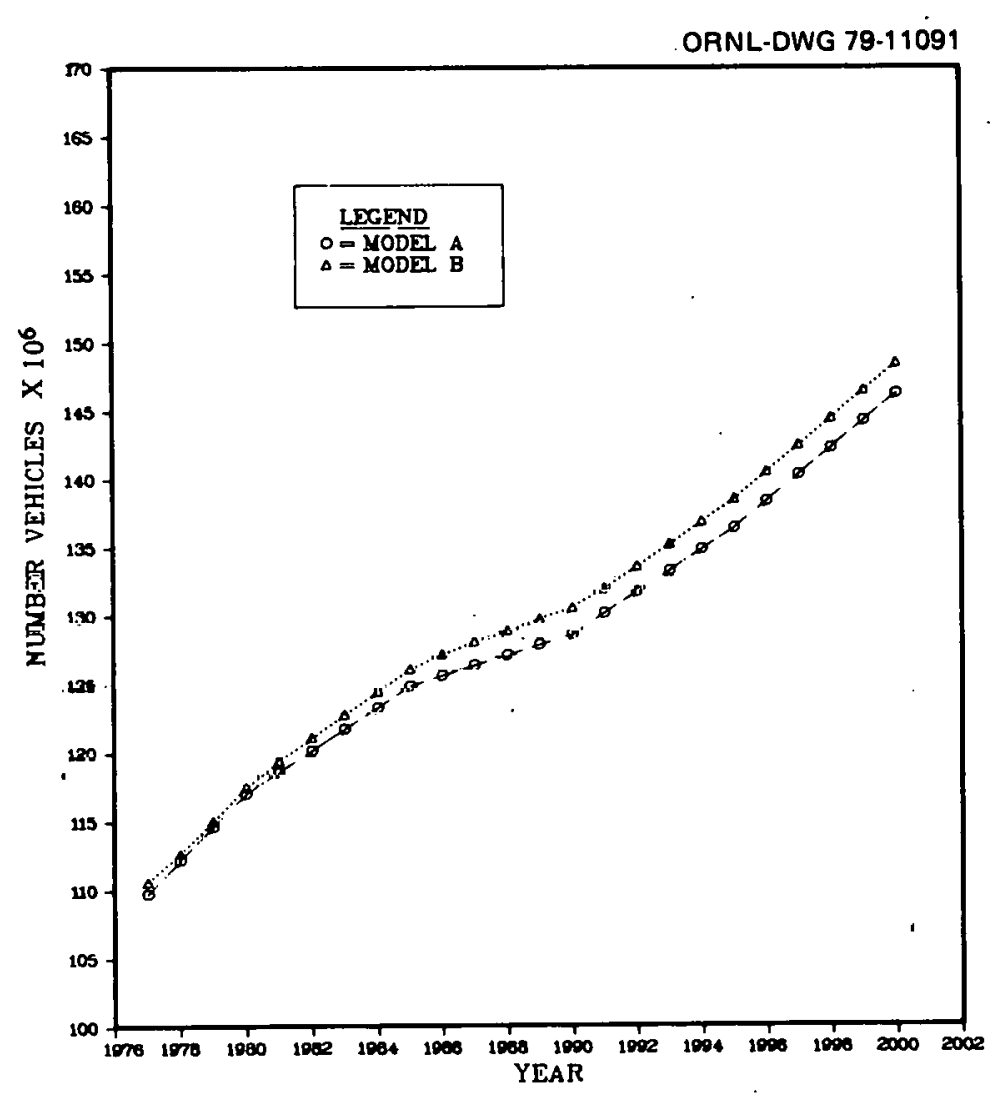

Fig. A.3. Automobile Forecast - Case IIA.

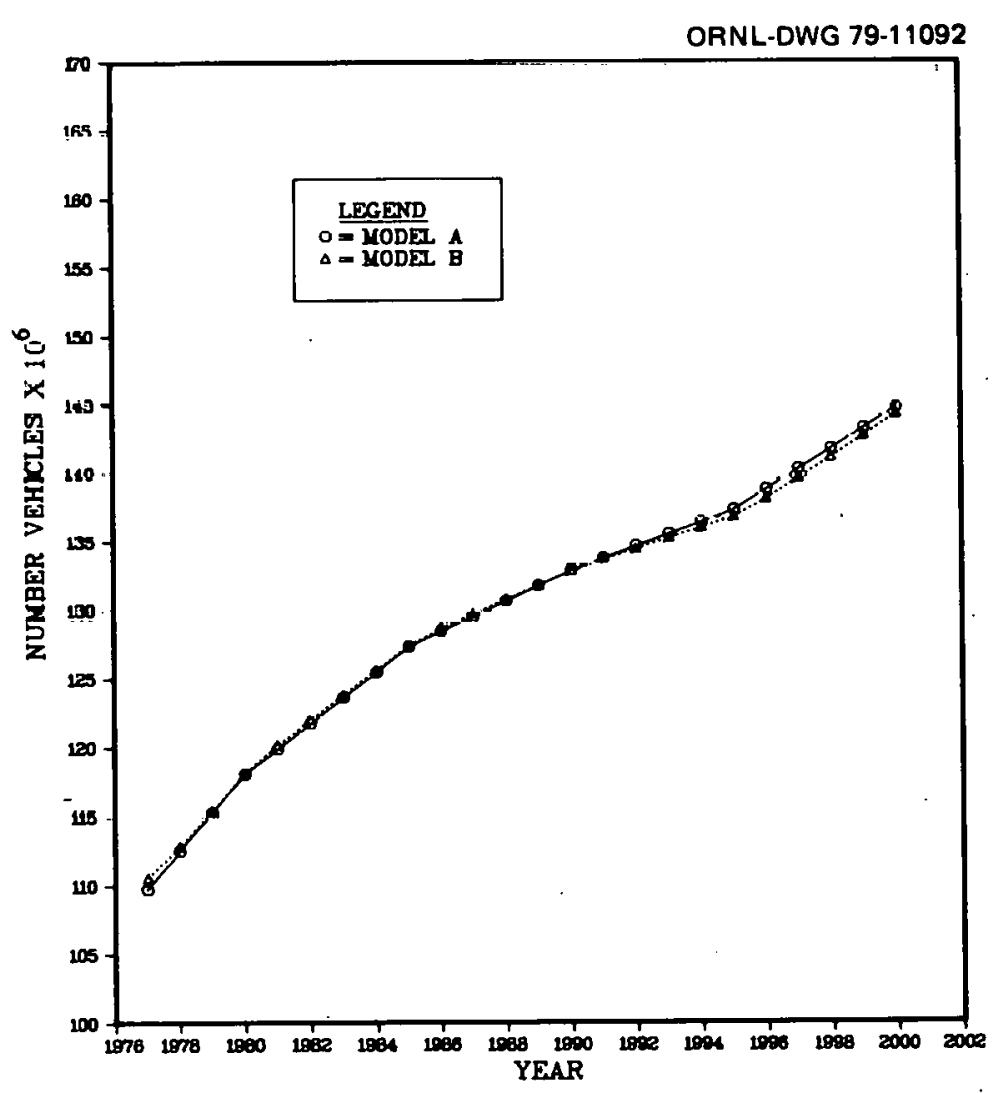

Fig. A.4. Automobile Forecast - Case III. 


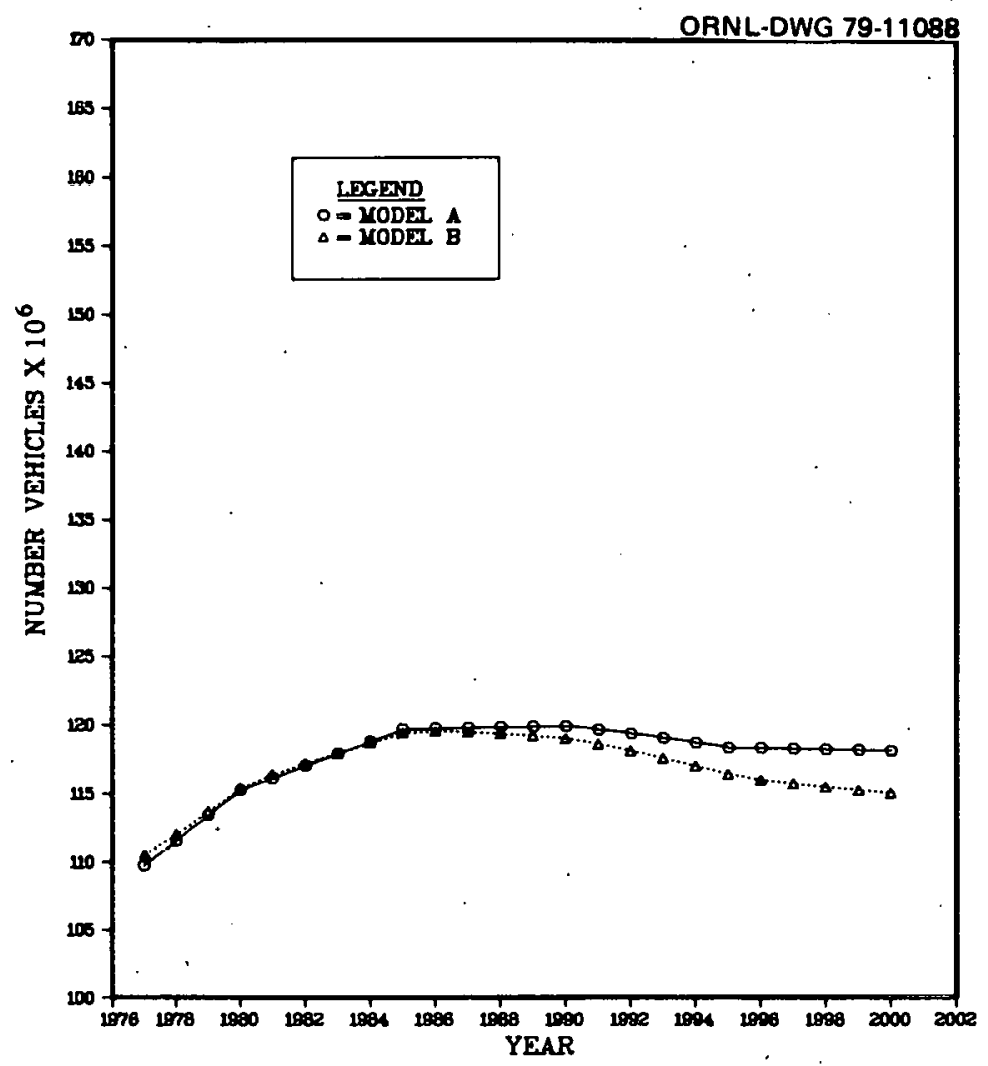

Fig. A.5. Automobile Forecast - Case IV.

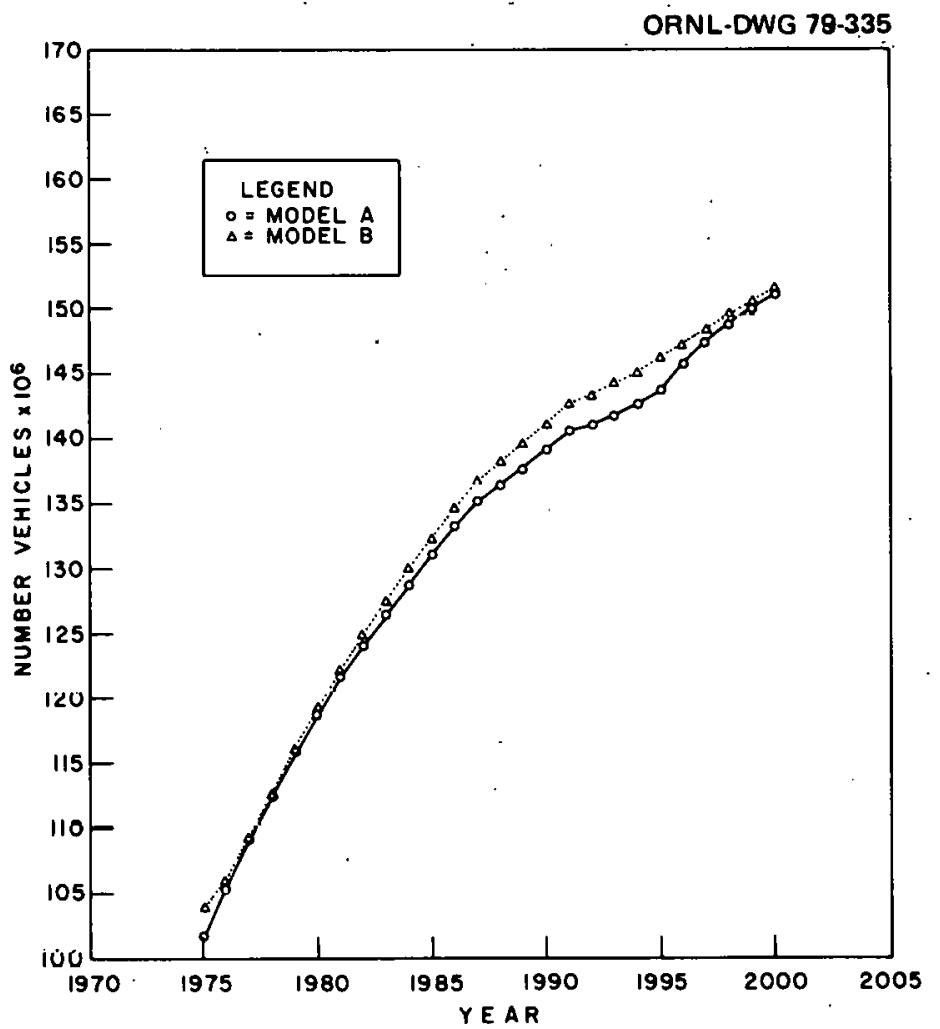

Fig. A.6. Automobile Forecast - Hirst Data. 
APPENDIX B

LIGHT TRUCK AND AUTOMOBILE FORECASTS 
THIS PAGE

WAS INTENTIONALLY

LEFT BLANK 


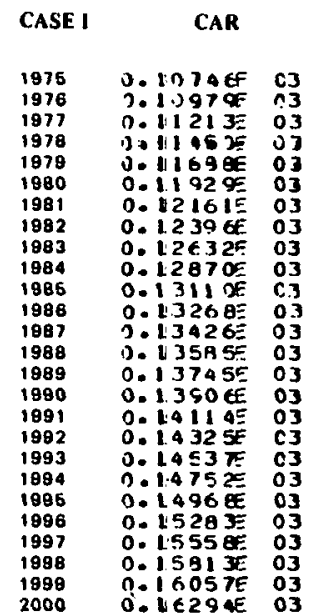

rotc

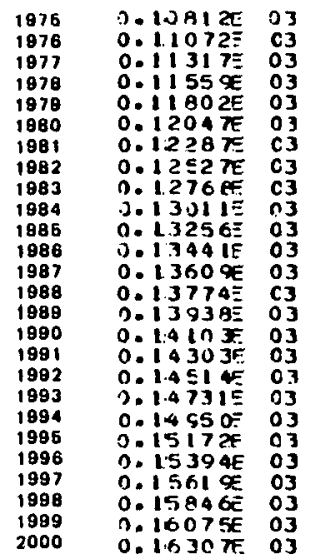

TR

$0.1896,2 E$ OZ $0.20312 E$ O? :.210155 92 $0.32477 F$ O2 $0.23936 \mathrm{E} \mathrm{O2}$ $0.25469 \varepsilon 02$ C. $26699 \mathrm{E}$ O2 $0.28024 E$ OD D. 29141 D2 O. $29821 E$ O2 $0.31221 E$ OP 3.32894 ER O. $34621 E$
02
$0.35455 E$

rotr

\begin{tabular}{|c|}
\hline 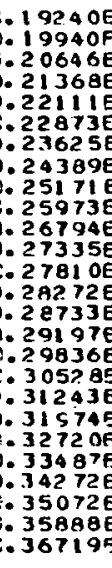 \\
\hline
\end{tabular}

CAR = NUMBER OF AUTOMOHILES (MODEL A) TR = NUMHEA OF THUCKS (MOUEL $B$ ) $S T S C=T R / C A R$

CARYOP $=$ CAR/POPULATION TRPOP $=$ TR/POPULATION
sTsc

$0.17645 E$ OO O.18114E OO O.1B596E O $0.19075 F$ OO
$0.19310 \mathrm{E}$ nO $0.19548 E$ OO 0.12003 J 00 $0.20124 E$ OO $0.20302 \mathrm{E}$ OO $0.20389 F 30$ $0.20476 E$
0.206475 00 0.20810 O OO 0.21164 DO $0.2152 .3 E$ CD $0.2170 B E$ OD $0.22091 E$ OO

TTTC

$0.17795 F$ OD $0.18009 E$ $0.18486 E 00$ 0.18734 O0 $\because 19986 E$ O0 $0.19470 E$ OD $0.19715 E$ OO 0.702136 J 0 0. $2 n 338 F$ on $0.20435 E$ OO $0.20526 E$ OD $0.20703 E 00$ $0.20860 E$ OO $.21209 E$ OO $0.21387 E$
$0.21566 E^{\circ}$ $0.21753 E$ OD $0.22133 E$ DO $0.22325 E$ O0

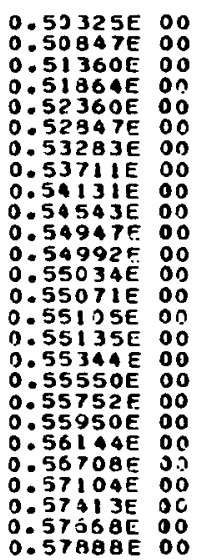

ToTrPo

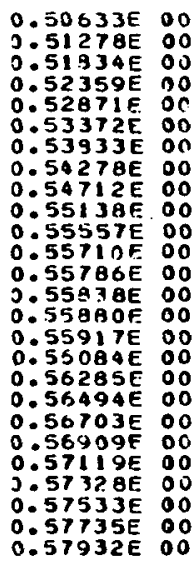

LECENI

VEHPOP $=($ TR + CAR $)$ PPOPULATION

HHSZ = IIOUSEHOLU SIZE

TOTC $=$ NUMBER OF AUTOMOBILES (MODEL B) TOTT = NUMBER OF TRUCKS (MODEL A) ITTC $=$ TOTT/TOTC

\begin{tabular}{|c|c|}
\hline TKPOP & VEHPOP \\
\hline 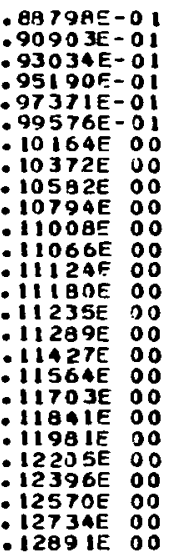 & 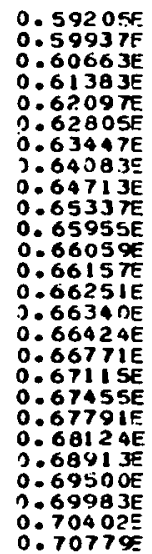 \\
\hline
\end{tabular}

TOTTPO

VEHCYO

$0.90100 E-01$
$0.92347=01$
0.96561 (34561F-O $0.99048 E-01$

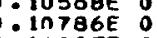
0.11007 ? $0: 11330 E$ 00 011401200 $0.11699 E$ OO 12127500 $0.12425 E$ O $0.12734 E$ OO $0.13045 E$ OD

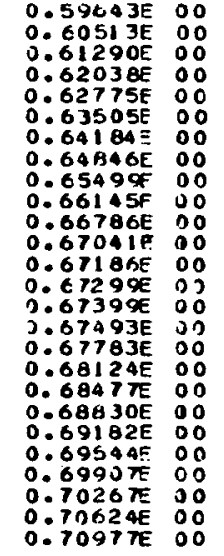

HISz

$0.29156 E 0$

-2ATzIE O

.205IIE oI

233 OSE O

OPYTIAE OI

$0.27532 E$ O

$0.27172 E$ OI
$0.26999 E$ OI

$0.26663 \mathrm{~F}$ ol

O.2650IE ?

O. $26189 E$ ?

0.25891 E

.24507e DI

0.2382HE OI

0.23014 O

ERR

$-0.93442 E 00$ -0.13690E OI $-0.14469 E$ or - 0.15 SOEE OI $-0.19337 \mathrm{O}$

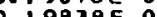
$0.23689 \mathrm{~F}$ $-0.25097 \mathrm{E}$ OI I7E of $.25964 \mathrm{E} D$ $\begin{array}{ll}-0.25801 E & 0 \\ -0.25024 E & \text { OI }\end{array}$ -0.2718BE OI $-0.6179 A E$
-0.55750 OD
MODEL A
TOTCPO $=$ TOTCIPOPULATION

TOTTPO $=$ TOTT/POPULATION

VEHCPO $=($ TOTT + TOTC $) /$ POPULATION

ERR $=($ CAR + TR $)-($ TOTC + TOTT $)$ 


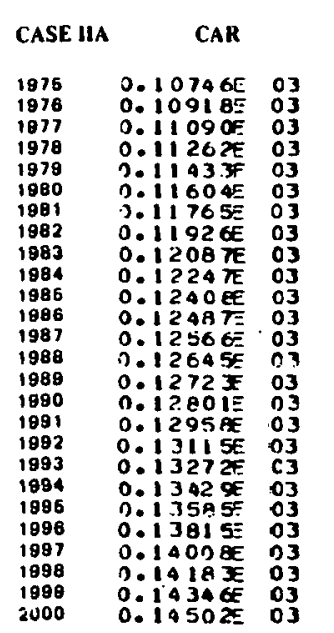

TOTC

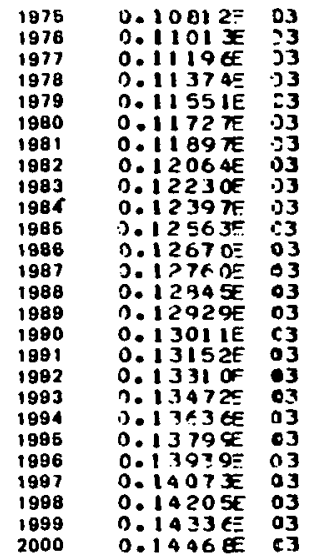

TR

$0.18962 E$ O2 c. $20001 E$ O2 O.Z1244E C2 $0.22415 E$ J2 $0.23591 E$ OL c. $24194 E$ O2 $0.25075 E$ OL $0.25341 E$ O? $0.25871 E$ O2 (1) 0.274076 N2
c.28060E O? $0.28723 E$ OL 0.301 OOE D2 ग. $30728 E$ O2 0. 31 A92E OP

\author{
TOIT
}

0.19240F 02 0. 2041 NE N2 0.21615E N2 $0.72245 E$ ก2. $0.22849 E$ O2 $0.24075 E$ O2 0. z4703F D? ח..25344F 02 0. $25712 E$ O? $0.26299 E$ O2 0.26859 O2 C.28761E O? ( 0. JOT15E D? 0. 31745E O2 0.327AAE O2
STSC

$0.17645 E$
$0.17874 F$ $0.18107 E 00$ $0.18824 E$ No $0.19052 E$ OO $0.17516 E$ O $0.19755 E$ OO $0.19994 \mathrm{E}$ ก $0.20081 E 00$ ก. 2ก25.)E J $0.20 .334 E$ OO $0.23416 E$ ij 0.20097 OO :.21142E 00 $0.213896 \mathrm{OF}$ $0.21787 E$ OD $0.21936 E$ UD $0.222 .35 E$ ON

TrTC

0.17795600 0.19237fe 00 0.1972DE OD $0.18969 E J 0$ $0.19206 E$ E $0444 E$
$0.19685 E$ 0.19928E 00 $0.2 n 294 F$. 00 $0.20474 E 00$ 0. DOSSOE OO 0.2064 JE OD O. $21098 E$ OO 2.21348F 00 $0.22193 E 00$ $0.2234 \mathrm{BE} 00$

CARPOP

TRPOP

VEHPOF

HHSZ

$0.50325 E$ OO O.5IJ3IE ON $0.51821 E 00$ 0.52303E 0O 0.52777E OO $0.53513 F$ OD $05418 E 00$ . $54808 E$ OD 0 $0.54886 E 00$ $0.54903 F$.0 - 5491 TE 0.5561 AE OJ 0.5595IE 00 $0.56281 E$. $0.57226 E$ OO 0.5805 TE 00 0.58380 ON
$0.58659 E$ ON

TOTCPO

$0.50633 E$ DO $0.51821 E 00$ $0.52 B 44 E$ OO J.5333BE OD $0.54231 E$ OO 0.54559 DO $0.55000 \mathrm{O}$
$0.55492 \mathrm{O}$ . $55640 E$ DO $0.5575 \mathrm{SE}$ DO 3.55790E OO 0.56007 DO $0.56139 E 00$ $0.56795 E 00$ $0.57496 E$ OO $.57739 E 00$ $3.57949 \mathrm{O}^{\circ} \mathrm{O}$ $0.58341 E 00$

\section{LEGEND}

VEHPOP $=(T R+$ CAR $) /$ POPULATION HHSZ = HOUSEHOLD SIZE

TOTC $=$ NUMBER OF AUTOMOBILES (MOUEL B) TOTT = NUMBER OF TRUCKS (MOUEL A) MTTC $=$ Torr/TOTC
0.88 T9AE - 0 $0.92946 E-0$ $0.95056 c-0$ $0.971905-01$ 0.10136501

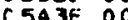
$0.10750 E$ OO $0: 10959 E$ :0 0.11064500 $0:$ IIIISF 00 0 i1212E OD $0.11622 E$ Jo 0 $0: 12468 E: 00$ $0: 1291_{1 E} 00$ $0: 139$ IE 00

Torrto

$0.301006-01$ $0.92323 E-01$ $0.96703 E-01$ $0.28925 F-01$ $3: 11117 E$ J० $0.10545 E$ jo $0.107590^{\circ}$ O:1097KF 00 $0.11292 F_{0} 00$ O.11415E O0 0.11523100 0 . I1699E 00 $011907 F$ O0 $0.12125 E$ ? $0.12861 F$ 00 $0: 13 i 29 E$ Oo

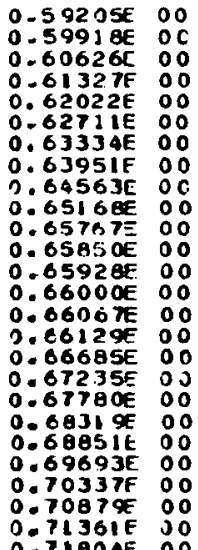

VEHCPO

$0.59643 E$ OJ $0.61272 E$ OO $0.62010 E$ OO $0.63456 E$ $0.64124 E$ O 0.66056 O 0.6668 J Jo $0.6700 \mathrm{TE}$ O0 0.672606 OD $0.67344 E$ OD O. 6934 TE O0 0.70065 . 00 ?:70462E OO O.70909E O0 O. YISTAF DO

$0.29156 \mathrm{~F}$ 0.2 ASIEE OI 0.281 IB OI $0.27923 E$ OI 0.2 055 ST OI C. 27194 E $0.26691 \mathrm{E}$ OI
$0.26532 \mathrm{E}$ OI 0.26376 E OI $0.26075 E$ OI 0.25930 OI O. 578 E $0.24535 E$ OI $0.23847 E$ OI 0.23 NOE OI

ERK

$-0.93442 E$ OO - 1 $-0.15609 E$ OI - 1163 SAE OI $0.18342 \mathrm{~F}$ OI $-0.19992 \mathrm{E}$ ol 0.260996 OI 0.27645 OI $-0.26207 \mathrm{nE}$ ol -0.28041 E OI $29126 \mathrm{E}$ O1 - 111463 E 0.26879 E 00
MOJJEL A

TOTCPO = TOTC,POPULATION TOTTPO $=$ TOTT BJPULATION

VEHCPO $=($ TOTI + TOTC $/$ POPULATMON

ERR $=($ CAR + TR $) \rightarrow($ TOIC + TOTT $)$
CARPCP $=$ CAR/POPULATION

TRPOP $=$ TR/POPULATION
CAR = NUMBER OF AUTCMOBLES (NODEL A

TR = NUMBER OF TRUCKS (MOUEL B) 
APPENDIX C

DESCRIPTION OF DATA 
THIS PAGE

WAS INTENTIONALLY

LEFT BLANK 
Table C.1. Description of Data

\begin{tabular}{|c|c|c|c|c|c|c|c|c|c|c|c|}
\hline YR & POPa & $\mathrm{HSE}^{b}$ & $\mathrm{AGE}^{c}$ & $\mathrm{HC}^{d}$ & $\mathrm{PCT}^{e}$ & UNEMP $f$ & тотт $^{g}$ & TOTC $^{h}$ & $\mathrm{GNP}^{i}$ & $\operatorname{cs}^{j}$ & $\mathrm{TS}^{k}$ \\
\hline 61 & 183.69 & 55.00 & 38.6 & 90.9 & 2205 & 6.7 & 8.269 & 63.420 & 755.3 & & \\
\hline 6.2 & 186.54 & 56.36 & 38.7 & 91.7 & 2272 & 5.5 & 8.750 & 66.110 & 799.1 & & \\
\hline 63 & 189.24 & 56.83 & 38.9 & 92.7 & 2321 & 5.7 & 8.911 & 69.055 & 830.7 & 7.941 & 0.934 \\
\hline 64 & 191.89 & 57.62 & 39.0 & 93.8 & 2452 & 5.2 & 9.883 & 71.983 & 874.4 & 8.319 & 1.050 \\
\hline 65 & 194.30 & 59.14 & 39.2 & 94.5 & 2571 & 4.5 & 10.586 & 75.251 & 925.9 & 9.546 & 1.194 \\
\hline 66 & 196.56 & 60.11 & 39.3 & 97.2 & 2672 & 3.8 & 11.261 & 78.123 & 981.0 & 9.264 & 1.294 \\
\hline 67 & 198.71 & 60.95 & 39.5 & 100.0 & 2740 & 3.8 & 11.908 & 80.414 & 1007.7 & 8.613 & 1.195 \\
\hline 68 & 200.71 & 62.72 & 39.7 & 104.2 & 2812 & 3.6 & 12.482 & 83.591 & 1051.8 & 9.849 & 1.446 \\
\hline 69 & 202.58 & 64.14 & 40.1 & 110.8 & 2833 & 3.5 & 13.197 & 86.852 & 1078.8 & 9.758 & 1.529 \\
\hline 70 & 204.38 & 65.25 & 40.6 & 118.9 & 2879 & 4.9 & 13.858 & 89.230 & 1075.3 & 8.827 & 1.456 \\
\hline 71 & 207.05 & 66.58 & 41.1 & 124.3 & 2958 & 5.9 & 14.664 & 92.754 & 1107.5 & 10.209 & 1.657 \\
\hline 72 & 208.85 & 68.25 & 41.7 & 129.2 & 3062 & 5.6 & 15.713 & 96.980 & 1171.1 & 10.919 & 2.094 \\
\hline 73 & 210.41 & 69.90 & 42.3 & $135: 0$ & 3225 & 4.9 & 17.211 & 101.763 & 1235.0 & 11.430 & 2.559 \\
\hline 74 & 211.90 & $71 . .35$ & 43.5 & 150.6 & 3143 & 5.6 & 18.562 & 105.290 & 1217.8 & 8.852 & 2.256 \\
\hline
\end{tabular}


$a_{\text {POP }}=$ U.S. population in $10^{6}$ people. Source: Department of Comrezce, Bureau of the Census, Current Fopulation Reports, Series P-25, Nos. 700 and 708.

$b_{\text {Number }}$ of fouseholds $\times 10^{6}$ calculated on the basis of average household size. Source: Department of Comerce, Bureau of the Census, Population Characteristics, Series P-20, No. 313, Sept ember 1977.

$c_{\text {Percentage }}$ ff popclation between the ages of 15 and 45 (interpolated). Source: Department of Commerce, Bureau of the Census, Statistical Abstract of the United States, 1977, Table 28, p. 27 .

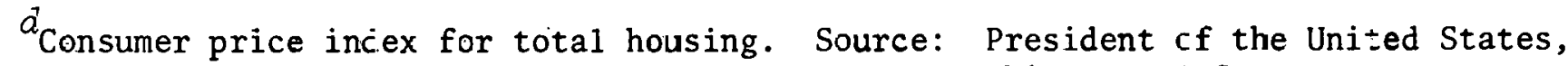
Economic Report cf the Fresident, Table B-49, p. 313, Washington, [.C.

e Per capita Jersonel cisposable income in 1967 dollars. Source: Pzesident of the United States, Economic 3eport of the President, Table B-22, p. 283, Washington. D.C., January 1978.

$f_{\text {Unemployment rate for all workers. Source: President of the United S }}$ ates, Economic Report of the President, Tajle B-29, p. 291.

9, inumber of 1 ight tricks, automobiles $\times 10^{6}$. Calculated on the basis of the 1963, 1967, and 1972 Truck Inventory ard Use Surveys and the 1975 Automobile Facts and Figures, Motor Vehicle Manufacturers Associaticn of the U.S., Inc., Detroit, 1975, p. 24.

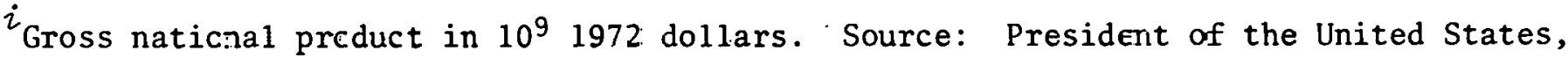
Economic Report of the Fresident, Table B-10, p. 269, Washington, [.C., -978.

${ }^{j}$ Car sales (both dcmestic and import sales in the United States). Sources: Automotive News, pp. 48, 68, 70 (1977); pp. 10, 54 (1976); pp. 10, 62 (1973); fp. 36, 16 (1965); p. 40 (1966); p. 19 (1959); p. 2C (1967); p. 14 (1971).

kight truck scies in the United States. Sources: Automative News: pp. 48, 68, 70 (1977); pp. 10, 54 (1976); p.p. 10, 62 (1973); pp. 36, 16 (1965); p. 40 (1966); p. 19 (1969); p. 20 (1967); p. 14 (1971). 
ORNL/TM-6450

\section{INTERNAL DISTRIBUTION}

1. J. T. Arehart

2. M. R. Chernick

3-47. Data Management and

Analysis Group

48: R. M. Davis

49-50. Energy and Environmental

Response Center
51. W. Fulkerson

52. G. Liepins

53-54. Central Research Library

55. Document Reference Section

56-57. Laboratory Records

58. Laboratory Records (RC)

59. ORNL Patent Office

\section{EXTERNAL DISTRIBUTION}

60. Assistant Manager, Office of Energy Research and Development, DOE-ORO

61. T. E. Benson, Department of Energy, 20 Massachusetts Avenue, Washington, D.C. 20585

62. J. Hayden Brody, Charles River Associates, 2727 Allen Parkway, Houston, TX 77019

63. Energy Division, North Carolina Department of Commerce, P.0. Box 25249, Raleigh, NC 27611

64. Kenneth W. Erdmann, Room 4102, Department of Transportation, 400 Seventh St., N.W., Washington, D.C. 20585

65. Kathy Erickson, Virginia Division of Energy, 310 Turner Road, Richmond, VA 23325

66. Kenneth Friedman, Office of Conservation and Solar Applications, 20 Massachusetts Ave., Washington, D.C. 20545

67. Charles Gray, Division Director, Emission Control Technology Division, MVEL 2565 Plymouth Rd., Ann Arbor, MI 48105

68. Dr. Thomas B. Griswold, Capitol Plaza Tower, Frankfort, KY 20601

69. Lawrence G. Hil1, EES Building 12, Argonne National Laboratory, 9700 South Cass Ave., Argonne, IL 60439

70-74. Edward L. Kaufman, Lindsey-Kaufman Co., 53 Hamilton Place, Tenafly, NJ 07670

75. Perry Kent, Federal Highway Administration, 400 Seventh St., S.W., Washington, D:C. 20590

76. Susan R. Law, Massachusetts Institute of Technology, Building E38-400, Cambridge, MA 02139

77. Clair E. Leslie, Science Applications, Inc., P.0. Box 843, Oak Ridge, TN 37830

78. Nancy Lewis, Librarian, Arkansas Energy Conservation and Policy Office, 960 Plaza West, ' Little Rock, AR 72205

79. Paul Lombard, Department of Energy, Washington, D.C. 20585

80. Thomas $F$. Mandel, Policy Analyst, SRI International, 333 Ravenswood Ave., Menlo Park, CA 94025

81. Robin Meyer, Georgia Office of Energy Resources, Room 615, 270 Washington Street, N.W., Atlanta, GA 30311 
82-83. L. M. Nolan, Dept. of Transportation Library, Acquisitions Section, 400 Seventh Street, N.W., Washington, D.C. 20590

84. Barry D. McNutt, Department of Energy, Room 7A139, Forrestal Building, 100 Independence Avenue, N.W., Washington, D.C. 20585

85. Barbara Otto, Regional Energy Information Center, Region VI, P.0. Box 35228, Dallas, TX 25235

86-160. Philip D. Patterson, Chief, Data Analysis Branch; Transportation Program, Department of Energy, 20 Massachusetts Avenue, Washington, D.C. 20545

161. Linda S. Popoff, Librarian, AIC 28333, Telegraph Road, Southfield, MI 48034

162. Leon M. Rudman, U.S. Department of Transportation, Transportation Systems Center, 55 Broadway, Cambridge, MA 02142

163. Rama Sastry. EV-231. E-201 GTN, Department of Enẹgy, Washington, D.C. 20545

164. Robert J. Skarr, Jack Faucett Associates Library, 5454 Wisconsin Avenue, Chevy Chase, MD 20015

165. R. A. Staley, Senior Economist, American 'l'rucking Association, 1616 P. Street, N.W., Washington, D.C. 20036

166. Robert Whitford, Potter Engineering Center, Purdue University, West Lafayette, IN 47907

167-173. Regional and Urban Studies Distribution, Energy Division

174-222. 'Data Management and Analysis Group, Energy Division

223-249. Technical Information Center, P.0. Box 62, Oak Ridge, TN 37830 